\title{
Слободан Грубачић
}

Филолошки факултет

Универзитет у Београду

bobo.grubacic@gmx.net

https://doi.org/10.18485/ai_knjiz_u_prevodu.2019.ch1

$81 ' 25$

\section{ПРИЛОГ КРИТИЦИ ЧИСТОГ ПРЕВОДА ${ }^{1}$}

Несигурни одавно, успињући се кроз редове оригинала и превода, поново смо на врху брега испод којег се крије неслућена маса теоријског леда. Тај невидљиви свет још није изронио на светло дана, упркос уверавању да никаквих тајни више нема, да се пробудила она што спава у ковчегу од стакла - богиња превода што књижевном делу удахњује други живот. Но и онај ко не зна да је превођење једна од најзагонетнијих пустоловина, зна да је веза између оригинала и превода дуга и дубока. У грађењу те везе, кроз време, простор и језике, повлашћено место задржава посредник, преводилац. Иако пребива у сенци текста, он у свом накнадном имагинативном елану корача истим стазама стваралачке маште којима је прошао и писац.

А превод, превод је „травестија”, рећи ће у свом огледу Шта је превод (1924) умни Улрих фон Виламовиц-Мелендорф, један од највећих класичних филолога у историји. „Он оставља душу, али она мења тело; превод је сеоба душе, метемпсихоза". У теорији књижев-

1 Текст преузет из књиге: Мапа текста / Слободан Грубачић. Сремски Карловци ; Нови Сад : Издавачка књижарница Зорана Стојановића, 2018 (Нови Сад : Сајнос). - 291 стр. ; 25 cm. - (Библиотека Синтезе / Издавачка књижарница Зорана Стојановића, Нови Сад). - Стр. 135-185 
ног превођења, међутим, таква метемпсихоза показује крупне претензије. Она значи позив да у тексту не тражимо само апстрактне механизме и моделе духа, него одјеке осећања и дубоких потреса од којих дрхти историја као и људска душа - заједно са строгом провером начела којима се служи савремена транслатологија.

„Плес у оковима” - слика којом је Ниче описао строге песничке школе у античкој Грчкој - може се с правом навести и као дефиниција превођења, у првом реду тамо где се ритам, метар и рима, већ и због сложености песничког идиома, опиру преводилачком прегнућу. Или где вишезначност нуди претерано велики изазов за нашу преводилачку страст укупношћу могућих углова читања.

Банална је истина да и сам преводилац упоређује себе са гласом лутке коју писац-трбухозборац носи са собом, у коју, заправо, пројектује свој сопствени глас, да би потом био изненађен због оног што лутка говори. И док књижевно дело изазовно пркоси неухватљивошћу свог садржајног богатства и непредвидљивим облицима свог испољавања, он се лако и радо приклања ставу професора физике и метафизике, Имануела Канта. То је став да ниједна доктрина превода није дорасла самом преводу - његовој „конгенијалној репродукцији у имагинацији”. Ту још није било речи о културним везама, о читалачкој публици, о хоризонту очекивања. Штавише, наредна епоха је довела у сумњу и оно што се најмање очекује: приоритет оригинала. Одрекла му је надмоћ, првенство, право примогенитуре.

Када данас читамо огледе из епохе класичног идеализма, из њих избија носталгија за хуманистичким изворима: туга за јединством незаборавног златног века преводилаштва. Било је то време када је заједнички дајмонион обавијао песника и његовог преводиоца. 
Време парадоксалног, и по свему вештачког, неприродног превођења грчких имена на латински језик, али и време грецизирања и латинизирања презимена, иза чијег се привидно дословног превода крио пренос целокупног искуства у сасвим другу врсту мишљења и знања. Translatio studii. Чинило се да ће преводилац постати незаобилазан и равноправан партнер у дијалогу култура а истовремено маг властитог, независног језичког обреда што непрекидно трага за погоднијим изражајним средствима у сусрету два света и њихових различитих језика.

Светац заштитник преводилаца, св. Јероним, творац латинске Вулгате, гласовитог превода према којем је Тридентски концил одредио канон Светог писма, формулисао је начелну дилему - дословност (verbum pro verbum) или смисао (sensum exprimere da sensu) - једну стратешку дилему која се столећима провлачи кроз западноевропске трактате о превођењу. Њему дугујемо и типологију преведених текстова: релацију између стратегије превођења и врсте превода. Дословни превод је препоручио за библијске текстове, превод према смислу за световне, и тако отворио хоризонте слободе и стваралачког замаха у складу са посебним одликама литерарног говора.

Лутер и Фауст, пак, двојица најмаркантнијих, симболичних ликова средњовековне историје превођења, били су суочени с озбиљним препрекама. Обојици се указао ђаво с намером да грубо прекине њихов преводилачки рад на Светом писму. Није лако вратити се у духу у оно време, мада сенке њихових огртача као да и сада промичу лелујаво и нечујно по каменим зидовима њихових преводилачких радионица. Траг црног мастила на зиду дворца у Вартбургу још увек сећа на тренутак када је непоколебљиви Лутер гађао сенку ђа- 
вола мастионицом. Знатно слабијег у вери и ширини деловања, ученог доктора Фауста је на превођење „светог оригинала” подстакло нешто друго - секуларна недоумица.

А када је пред њега стао нечастиви, цинични Мефистофелес, та се недоумица није смањила, напротив. Његов транскрипт врви од силних коректура: Фауст не зна како би превео Логос из уводне реченице Светог писма (На почешку беше логос). Сметен је, збуњен, не само зато што се Ђаво прерушио у новог Јеронима. „Морам то другачије превести”, каже Фауст у себи, „ако ме је већ дух просветлио", па наизменице записује смисао, снага, реч и најзад дело, то јест чин, удаљавајући се од изворног превода Речи. Задржати се на томе значило је за Гетеа антиципирати, осим теологије речи, и метафизику Идеја и поетику просветљења. Дух му онда заиста прискаче у помоћ, јер на почетку је доиста било - дело. Сада Фауст, свестан семантичког померања, испитује границе своје слободе и ствара сопствену теорију превођења. Чаробна „реч” Лутерова губи битку, у којој нема заробљених и преживелих. Почиње пародија: јер, израз „дело” је заправо сугестија једног у сваком погледу овејаног ђавола, Мефиста, који је нераздвојни део Фаустове сопствене личности, и који њему, Фаусту, спремном да се ода магији, свему што води тајнама коначног сазнања - буквално „даје крила” (Flügel wachsen lassen).

Иза ових луциферских сцена крију се ликови Јакова, анђела, чаробњака, научника и усамљеног калуђера нагнутог над текстом у високо засвођеној, тесној, готској соби. Још увек се, упркос свакој вероватноћи, помишља да су им негде на небу намењени суседни кабинети: веровеснику Лутеру и професору Фаусту. Нова наука се, по томе, родила из два извора: теолошко-филозофског и уметничког, да би временом постала 
дисциплина различитих филолошких и педагошко-методолошких система. Данас је основно разликовање постало јасније: скепса према речи разликује филологију од теологије. И док ће наредна столећа видети основу постојања или у духу или у материји, у природи или у бивству - чему ће Дерида придодати бизарни префикс пост - нама је, сада и овде, најважнији знаковити учинак доктора Фауста. „Принц научне меланхолије” и један од двојице симбола верске и мисаоне Европе, поникао је на другачијем сазнајном искуству.

Није сад реч о томе да ли је Гете овде злоупотребио хришћанске симболе за уметничке и арабескне ефекте. Наступивши у духу новог доба, у коме смисао постаје елегантни непријатељ дословности, Фауст је обновио сумњу у радикалност поделе у основној дилеми превођења - верност или креативност, уметност или слобода, дословност или „доместикација”. У свему томе, међутим, лик ђавола нема само метафорични смисао. Он представља персонификацију пуке целебралности, апстрактне интелигенције, чистог ума. Његова улога је улога радикалне скепсе, која у исти мах подстиче и кочи. То објашњава због чега је преводилац ђавољи адвокат.

Но таква дефиниција је зацело недостатна, јер се иза свега крије једно још радикалније питање. То је питање свих питања, или још прецизније, питање пре свих питања: да ли је превођење уопште могуће? У једном свитку хебрејске хронике из првог века пре нове epe (Megillat taanit), тврди се да је наступило тродневно помрачење сунца након што је Закон био преведен на грчки језик. Био је то трагичан дан за Израел када су, по налогу краља Птоломеја, седамдесет и два мудраца превела Тору. Тај чин о којем извештава Талмуд (Megilla 9a) значио је крађу мудрости: губитак или отуђење оригинала исто је што и губитак јединствено- 
сти, самосвојности, неупоредивости. Наравно, оно што je, у симболичном смислу, хебрејски свитак заправо сугерисао, јесте чињеница коју сваки преводилац мора да призна: превођење увек значи губитак.

Тек ће у 20. веку бити у потпуности изражено супротно становиште, нешто што је такорећи рђава савест добре рационалистичке свести и коначно колебање духова који се баве проблемима превођења. Нешто што се опире и буни у нама против таквих редукционистичких подухвата. Борхес ће у том контексту говорити о својеврсном празноверју. Ту се већ отворено доводе у сумњу неодмерене претензије оригинала; еластични идентитет къижевног текста измиче коначном вредновању или се измешта на маргину разматрања као питање мањег значаја. Ниједан текст се не може сматрати „непомерљивим спомеником”, тек се у поновљеном читању, у потреби за верификацијом првобитног утиска, може донети суд о његовој коначности. Стога се и пресудна значења ових поларитета могу мирне душе додатно продубити. Да ли превод треба читати као оригинал, или као информацију о њему? Треба ли га у духу и смислу оригинала поправљати, или прилагођавати у складу с такозваном ars applicandi, какву је захтевала и средњовековна херменеутика? Да ли је, најзад, превод нека врста гипсаног одливка изворног лика и коิда текста, или је свесно конципиран само као наговештај готовог модела, непоновљивог оригинала?

Равно три века стајала је европска историја превођења у знаку „лепе невернице” (belles infideles). У складу с овом синтагмом, насталом поводом Дабланкуровог (D’Ablancourt) превода Лукијана, верност оригиналу су преводиоци заговарали само у теорији. По правилу су им обзири према читаоцу били важнији: излазећи у сусрет укусу, веровали су да превод треба објаснити, 
улепшати, модернизовати и на све могуће начине приближити домаћој публици. Тражећи излаз за речи и проблеме који га тиште, наоружан стрпљењем, отпоран на неразумевање, преводилац је од давнина приказан и као биће које утире пут до средине која ће прихватити „његовог” аутора, како би и она осетила исто задовољство од дружења с његовим текстом, онај сладак заборав коме се губе сви немири, сви страхови, све непријатне помисли. Разгрнемо ли завесу испред те средине, видећемо судбину преводиоца на позорници књижевне историје, виђену из сентименталног партера. У њој још увек живи романтична представа о преводиоцу у коме се све отима да преведе оно што је у њему такло најинтимније струне, али и да, у наступу свог племенитог стваралачког лудила, у исти мах вешто сакрије у чему се састоји цела загонетка и тајна његовог умећа.

Знамо да многи у томе данас виде споменик преводилачкој егоманији. Штавише, украшавају га венцима синтагми о „фундаменталној антипатији” која постоји између превода и његове теорије. О трајној супротности између динамичког процеса и статичног модела. Ни средство откривања истине, ни „спознаја у сликама”, теорија превођења се табуира као излишна, одрешена од креативног живота, од везаности за текст. Одвећ крута и догматска, осуђена је, кажу, да буде без душе, као што је и њена трајна дефиниција осуђена на пропаст. Ако унапред знамо да задатак превода није садржан само у томе да реконструише смисао и поруку дела, већ и његов систем, његову формалну структуру која омогућује преношење тог смисла - онда нам се теорија више не указује као пуко средство откривања суштине преводилачког подухвата.

Али, ако је пракса превођења могла да заборави теорију, теорија није заборавила њу. Не може се, додуше, 
порећи да су дефиниције транслатологије, које сама теорија нуди, често само оштроумни парадокси што осветљавају ову или ону комбинацију, ову или ону колизију која се сваки дан понавља, те тако у преводиоцу види предмет практичног експеримента, објекат изучавања вероватноће, уверљивости и могућности обнављања самог експеримента као таквог. Па ипак, чињеница је да са сваким новим преводом расте и број нових одговора, што несумњиво доводи до теоретских померања.

Има истине и у претпоставци да се вековни проблем интерпретације текста појавио истовремено кад и проблем превођења. Изазов херменеутике искрснуо је већ у тренутку када су она седамдесет и два ученака били раздвојени по собама, како би сваки од њих писао своју верзију превода. Ако их и није оптужио да су изневерили Реч Божју, краљ Птоломеј је очигледно хтео да их збуни, сукоби и тиме дискредитује и њих, и Тору, и снагу њиховог веровања. Захваљујући овим различитим преводима, била би, у суштини, омогућена противречна тумачења текста, но то би сви други осим Јевреја доживели као ману или огрешење, јер за њих није важило гесло: „Где влада несагласје, нема истине”. Tора је, наводно, свесно писана тако да стихови, речи и слова омогућују разнолика тумачења.

Сетимо се Шагалове слике на којој видимо двојицу старих Јевреја окренутих наглавачке како читају Тору. Нека ту слику свако тумачи како жели - макар и наопако - чињеница је да се њоме не илуструју литерарни греси неуких читалаца. Напротив, слика драматично наглашава како свака поједина реч, па и текст у целини, представља место укрштања различитих, па и потивречних значења. Дословни превод светих спиca (Peschat), који Мишра ионако забрањује, сматран је, осим тога, за грубу симплификацију, за најнижи од че- 
тири метода које су прописивале теорије тумачења. Већ много пре него што ће се на њу надовезати утицајна подела полихистора Аугуста Бека, позна јесен схоластике нам је оставила изванредно сведочанство о чудесном трајању такве систематизације, у којој процес спознаје никада није окончан:

littera gesta docet, quid credas allegoria moralis quid agas, quo tendas angogia

Но ако се и данас у њој, у теорији тумачења, види само празни модел рационалности и једнострано одређење суштине, то не значи да нам се, заузврат, нуде тезе о преводилаштву које су мање апстрактне. Или мање тајновите. По њима, наиме, све супротности, све антиномије списатељског и преводилачког чина, ма колико противречне, пресудно важне или узгредно акциденталне изгледале, налазе своје измирење у загонетној дубини јединственог духовног простора чије празнине испуњава „могућност речи”.

Могу ли се онда сматрати коначним сва она надмена уверавања да су успешни преводиоци истовремено и безгрешни титулари истине који не пате много од колебања у алтернативама? Овде се приближавамо језгру неспоразума. Јер уместо да тврде како нису пуки инструмент и медијум ширења уметности, они би се, заправо, морали представљати као апостоли културе. Као бића која у себи носе идеју цивилизацијског послања као своју најдубљу истину. Утолико пре што, уз многе слике које се тичу пута и приспећа, нуде и једну за превођење посебно архетипску слику: пловидбу на пучини и прелазак на другу обалу.

Преводи повезују обале нација, њихове идеје и културна добра, као што су антички сплавари знали пре- 
вести робу и људе, посреднике добре воље и гласнике међусобног уважавања и дивљења. Слика пловидбе донела је теоретичарима 18. века пролом: продирање у свест свога задатка. „Превести”, говорио је и Јакоб Грим, има два значења: превести на другу обалу и превести књигу. Tracudere navem. Носећи драгоцени товар и пловећи против струје језика, избегавајући буру, хриди и подводне гребене, преводиоци су ипак осећали, назирали, слутећи схватали органски развојну повезаност култура. Сањали су о унутарњим цивилизацијским законима постојања. Призивали неку Универзалну светску културу, чију непрегледну „преводну разноврсност” је Хердер, самозвани „проповедник врлине свог доба”, спознао у расправи О пореклу језика $(1770, \mathrm{XП)} \mathrm{као} \mathrm{пут}$ ка чистој човечности: „Кад бисмо само имали такво огледало људског рода у свој својој верности и пуноћи"!

С друге стране тог огледала, међутим, крило се и нешто друго. У чувеном есеју Сјај и беда превода (1937), Ортега и Гасет ће епиграмски сажето, с духовитим психолошким запажањима, истицати затамљени, амбивалентни карактер односа измебу емпатије и дистанце приликом превођења. Пошто различити језици крију различите ствари, најтеже је, каже, „преводити оно што се прећуткује". Но ту се одмах може наслутити од како велике, далекосежне важности може бити превођење: као „наизменично разоткривање тајни” које народи и векови љубоморно „чувају за себе”, а које „толико доприносе њиховој раздвојености и непријатељству”. Такорећи у истом даху се овде рекогносцирају две ствари: и оно што једна култура крије или природно нуди другој, и оно што је спремна да прими од друге. И miseria, као сизифовски јад или безнадежно утопијски карактер прихватања и адаптације, и esplendor, као теоријско узвисивање племенитости у преводилачком чину. 
Али овде се одмах као одговор јавља и нешто треће, до чега се углавном долази посредним путем. На самом крају, наиме, налазимо и један управо теоријски разлог: свест да се и сам појам превода мења, еволуира, заједно с новим преводима. Тај се феномен непрекидно обнавља. Он је вечно враћање, али то никад није враћање истог. Јер је тако нешто немогуће: призивање слика и симбола једног могућег света и његово везивање за наша реална искуства омогућује не само трајност пишчеве поруке, него и њене преображаје и ревизију значења са сваком генерацијом читалаца. Јер, велико је питање шта се то све, током векова, мења и збива у главама читалаца, док у средњовековном костиму, под шлемом, шеширом, а и сасвим без капе, стоје пред истим, загонетним књижевним огледалом.

Отуда ни историја превођења није историја доктрина сачуваних у знаменитим текстовима, већ пре историја издвојених покушаја. Готово би се могло рећи да је реч о паралелној историји неодољиве и-све-друго-потискујуће потребе за приближавањем, за трансфером култура, у којем преводиоци могу бити независни од много чега, од моде, чак и од логике, али не могу бити независни од изворника.

Стога је и циљ овог пролога анализа појмова „превод” и „књижевна историја”. Нагласак лежи на томе да се оба ова појма, повезана, односно супротстављена у овој мање или више популарно третираној формулацији, прецизније одреде у смислу њихове спреге него што се то обично чини у практичној употреби књижевноисторијских разматрања. Ако, на пример, преводилац и јесте нека врста ауторовог алтер ега, ако његов превод и јесте нека врста Елиотовог „објективног корелата”, он ипак није пуки творбени лик који читаоцу нуди ауторову измаштану стварност, већ нека врста самосталног медијума, ослобођеног од ауторове воље, који иде у су- 
срет читаоцу чија свест се не поклапа са ауторовом. У непризнатом сукобу с њим, у трајном искушењу да догради или изнова створи, он осећа да му на раменима седе она два анђела Еразма Ротердамског што записују рђаве и добре мисли док гледа у дуге редове слова.

Зато је и свака рецепција, свако читање, опет нека врста превода. Ступајући у конкурентски однос са оригиналом, постаје само друга врста подстицаја или инспиративног модела - као мета-текст, који се удвостручује или трансцендира своје порекло. Сетимо се, најзад, шта је у Крсташким походима једног филолога (1762) рекао о томе ирационалиста Хаман, једна од амблемских фигура немачког идеализма: сваки говор је већ превођење; сваки чин писања и читања у суштини је превођење са језика анђела. Бог је, каже он, песник а не математичар, а истина увек говори у загонеткама.

Доле, у низијама преводилачких радионица, ствари већ не изгледају тако високопарно. Ту је већ много теже видети у преводиоцу христоликог подвижника и мученика верности. Штавише, темељ велике верности превода је, најпре, велико - неверство. Преводилац је Протеј. Начелни дуалиста. И то је чињеница која се осећа чак и у синтаксичком построју. Преводилац мора знати и волети страни језик колико и матерњи па да стихове у његовом преводу осетимо, да наслутимо и познамо откуда су и чији су, али и да их заволимо као да су наши. Двострука илузија истине и верности!

Текст је за читаоца, према тој идеалистичкој идеологији, тек пука представа; у том правцу би, отуда, била могућа и нека кантовска Критика чистог превода. Па и критика читалачког доживљаја, ако га, рецимо, видимо као Шопенхауер: „Када читамо”, каже аутор Света као волье и представе, „неко други мисли и осећа за нас”. Али прави феноменолошки део приче тек следи. Нема сумње 
да је свако читање радикалан прекид у континууму нашег подруштвљавања. Шта тај прекид представља? Бекство, ескапизам? Свакако и то, али оно што моћ књижевности чини незаменљивом - чак и у добу визуелног тоталитаризма - остаје непромењено. Нема, наиме, никакве сумње да читање има духовну функцију као самоизграђивање властитих мисли, у чему и лежи основни парадокс: препуштајући се књизи неког аутора, налазимо заправо своју непоновљиву индивидуалност.

Тај парадокс је, при том, двострук: у поновном читању исти текст доживљавамо увек на другачији начин. Кад год се враћамо некој књизи, у њој је нов свет, нови дух, нова књига. Доживљај подсећа на одаје обложене огледалима, а ти кабинети умножавају лик са свих страна у недоглед. Науку о превођењу све више занима то призматично преламање значења по којем су све верзије тумачења историјски условљене. Из тога произлази и премиса да већ поменути еластични идентитет књижевног дела, а самим тим и његов дионизијски карактер, надмашују ону езотеричну аполинијску, то јест, једносмерну симпатију према тзв. интерлинеарној верзији као једино истинитом преводу: тек нам се у укупности својих верзија, едицида и превода дело указује као надређени, књижевни систем.

Али ни њега постмодерна не сматра јединствено објективним и непоновљивим, и уместо тога заступа став да све верзије фиктивне стварности већ по дефиницији чине поприште различитих интерпретација. Знамо да је школа позната као деконструкција фаворизовала разиграни сукоб интерпретација: истина је плурална, у сталном процесу самопотврђивања и освајања аутентичности. На супротној страни је догматизам, тенденција да се свет тумачи једнозначно, за невољу и дуалистички, манихејски, као црно или бело. 
И као што нема коначне дефиниције читалачког доживљаја, тако нема ни идеалног пута који повезује читаоца са текстом - нема га у теорији, нема ни у пракси, а нема ни једноставног решења за проблем чији историјски аспект нестаје у библиотеци у којој, листајући, нагнути над књигом, не препознајемо само успомене што тињају у нама као паралелни живот, као познате ситуације или као поновљене властите емоције у искуству другог. Ми их уписујемо у талог нашег властитог искуства као увек нове, и увек другачије оријентире промишљања стварности, иако се, по некој чудној инерцији, стално говори о вечним датостима и коначним сазнањима.

Умесно је, међутим, питање да ли уопште постоји онај Изеров „идеални читалац” чија свест би једнако покривала текстове оригинала и превода. Неко ко би, попут старца Тиресије, био гласник оба света. Иако свесни ове предрасуде, многи писци су, знамо, преводили сопствене текстове: Семјуел Бекет је своје драме, песме и приповетке преводио с француског на енглески и обратно - није никаква тајна да се ови преводи драстично разликују од оригинала. Много је тога што подразумева интердисциплинарни приступ култури превођења, разликама у менталитету, колективном идентитету, културном памћењу и перцепцији свог и туђег.

Са тим разликама се на вишем, културолошком нивоу, повремено отварају понори. Штавише, целокупна културна размена у историји идеја почива више на искривљавању и неспоразуму него на истинском разумевању, сасвим у духу француске теорије о „лепој неверници", због чега је Гете поредио преводиоце са вештим трговцима који, хвалећи напола скривено лице лепотице, буде радозналост и жељу да се види оригинал. Целокупна светска књижевност је, радикално форму- 
лисано, обмана, фатаморгана, привид аутентичности, бескрајни низ наслућивања и самозаваравања. Али подстицајни могу бити упркос свему. Милорад Павић je, каже, открио поезију погрешно разумевајући француске текстове. Када је научио језик и вратио се тим текстовима више ничега није било од магије. „Све се расплинуло као мехур".

Ако је, пак, с друге стране, целокупна историја књижевности, културе уопште, само „превод низа превода" (Октавио Паз), ако масовна продукција књижевних текстова, данас, има фаталну судбину, онда се с правом наглашава разлика између продуктивних и непродуктивних неспоразума. Као надасве продуктиван поетски неспоразум показао се већ у давна времена мит о једнорогу. Захваљујући погрешном преводу једне речи у Библији, која означава једну далеко мање привлачну животињу, непостојећи, волшебни једнорог, заједно са заводљивом сликом дуге, отворио је двери неког чаробног, бајковитог света, али га налазимо и на разним грбовима, хришћанским минијатурама, ренесансним сликама, па и на шкотској верзији британског краљевског грба.

Продуктивни неспоразум представља такође, истина на вишем мисаоном нивоу, Сартрова искривљена рецепција Мартина Хајдегера. Сам Хајдегер је, опет, сматрао да се целокупна духовна историја Запада налази на странпутици. Пошла је кривим путем захваљујући - погрешном преводу. Трагајући за изворним значењем, велики теоретичар „пута” приписао је то једном једином, кључном превиду, због којег је грчко енергеиа преведено са actus. Мање штете је зацело нанела околност да је гласовитом француском филозофу недостајало подробније познавање немачког језика и неки иоле пристојан превод Бивствована и времена. Оно што је из свега тога произашло, изазвало је код многих немачких хајдеге- 
ријанаца ужасавање или благи презир, али је у исти мах несумњиво унапредило конзистентност и филијацију Сартрове сопствене мисли. Он је унео бројне неологизме у француско филозофско мишљење; иако их човек при читању француског текста схвата тек када их пребаци назад, у њихово првобитно немачко окружење, покушај филозофског обогаћења је убедљиво демонстриран. Непродуктивни неспоразум, с друге стране, представља ван сваке сумње насилна преводилачка актуелизација Фихтеа, Хегела и Маркса према интелектуалном профилу нових француских филозофа.

2.

Превод као воља и представа. - Истини на вољу, сваки преводилачки чин је нужно деструктиван јер претпоставља нарушавање једне већ обликоване целине. Без обзира што у својој основи чува њен смисао и садржи елементе стилског усаглашавања, он редовно модификује и деформише уметничку целовитост, настојећи да је оствари у једној другој, аналогној равни. Рушење и грађење су му инхерентни. Превођење је сложена духовна дисциплина. Преводиоци су емпирици, дакле песимисти. Свесни својих ограничености, знају да је превођење тегобна ствар. Али у исти мах су маштовити људи, дакле уметници, те њихов песимизам нема ону метафизичку дубину, коју налазимо код филозофа. Код ових, уосталом, од Платона наовамо, влада мишљење да се писменим путем не може пренети филозофска мисао, поготово не путем преводилаца. А они и нису личности него „званични илузионисти-вентрилоци” што доводе до стилизације и позориште лутака, скуп механичких гестова и речи.

Заокупљен текстом, у његовој служби и добровољни инструмент самог текста, преводилац се не служи 
пуким помирењем духовне климе са формалном структуром текста, него управо настоји да проникне у загонетни сплет односа с којим је текст везан за епоху, институције, идеје, начин понашања и деловања човека. Стога је историчару и теоретичару књижевности мање важна практична појавност текста у књижевном „погону”, а много више његово призматично светлуцање у разбијеним огледалима времена.

Отуда друга дилема: да ли посегнути за стилом и вокабуларом, урбаним или рустичним свеједно, који би одговарао времену и духу, менталитету оригинала, или напросто увести лексику која својом универзалношћу повезује највећи број читалаца - оних којима је укус њиховог окружења највернији сеизмограф естетског искуства. Још више: да ли да, полазећи од своје властите метафизике, преводилац тражи свој језички простор између своје властите стварности и имагинарног света текста.

Узнемирени због таквог сазнања, морамо призвати у свест управо њу, свест. До сада је било речи о превођеном тексту, сада је реч о свести преводиоца. Важно је знати да се ту не ради о новом проблему, како би се могло помислити, већ заправо о истом. Да би се то прихватило, треба одустати од два класична модела тумачења, који замагљују феномен. Први погубни модел je, изнова, али овај пут у преводиоцу - модел самосвести. Има нечег симболичног у томе како „писац и његова сенка”, као Кастор и Полукс, шестаре бескрајним простором текста као нераздвојни пар. Али преводилац се не поистовећује с ауторовим гласом; он мења регистар - мада је и он, већ код првог читања оригинала, потписао уговор о веровању у фикцију.

Али, не остаје ли онда изван дела, као онај који суди, своди рачуне, заокружује доживљај? „Обични” читалац оличава модел заслепљености - преводилац, пак, модел луцидности који доживљава текст на начин 
лажне свести. Између оба та екстрема, која се не могу замислити у потпуној идеалности, креће се душевни ритам преводиоца. Али само зато да би својом вољом био ухваћен у ту привидну дистанцу, у ту страност да би од њега била начињена сама ова дистанца, која није ништа друго до делатна и делотворна ре-креација, ништа друго до репродуктивна интерпретација.

Другим речима, преведени текст јесте свест преводиоца, управо зато што он, по речима Гадамера, и нема друге свести до језика који га сједињује с текстом, и развоја тог језика у тексту. Из тога нам се онда намеће закључак да је превод само нови резултат који се у тексту производи полазећи од овог препознавања, чија је он, опет, језичка слика и представа. У то се, онда, савршено уклапа дефиниција читања као психолингвистичке игре препознавања и предвиђања. Не може бити случајно што стара грчка реч „препознавање” (анагнорuсис) данас значи „читање”. Али је наивно упућивати на филозофски проблем превођења кроз удвајағе на биће и сенку. Погрешно је, наиме, када се из тога закључује да превођење спутава развој сопствене оригиналности, иако се мора признати да није било епохе која то није доводила у питање.

Потребно је, такође, одбацити и онај други модел преводилачке свести: модел идентификације. Анализа психолошких процеса ионако носи у себи опасност да се западне у психологизам; а сумњиво изједначавање које полази од феномена пројекције и сублимације не може само по себи да објасни - осим, наравно, алегоријски - друштвену, културно-естетску и идеолошку улогу препознавања и само-препознавања. Не може да објасни тај сусрет са Истим у облику Другог, у коме преводилац види свет кроз нека другачије обојена стакла и свакако дубљим, епифанијским погледом. У коме не 
жели да буде оно што у њему види аутор - пуки посредник, нека врста млетачког Шајлока који тргује телом текста, како га види Жак Дерида; или само безимени двојник иза огледала, уљез у туђој кући, лопов у башти који на сваком листу, намерно, оставља отиске својих прстију. А да сваки преводилац нужно и неизбрисиво оставља отиске својих прстију, у то, такође, нема и не може бити никакве сумње.

Преводиоии-апотекари. - Поред ове симболике кода одређује својеврсни тактилни однос преводилаца према тексту, не подлеже сумњи ни чињеница да је у средњем веку доиста постојало веровање у психосоматске процесе и буквалну телесну везу са преведеним садржајем као узроком свих других узрока, а и саме њихове узрочности. То веровање, неговано у полуманастирским мислилачким школама и у сенци стародревних светилишта било је по свему ексклузивно. Било је исто тако верно чувано као готичка схоластика на потпуно духовним универзитетима барока. Тајне преводилаштва биле су ствар неколицине, сталешки посед, за шире слојеве недостижан и неразумљив, па је и њихова мистика била ограничена на уске кругове изабраних, запечаћена латинштином и тежином слика и појмова, уопште нејасно сазнатљива у свом постојању.

Јер, када је крајем 12. века доживела процват преводилачка школа у Толеду, једнако славна као и она сицилијанска коју је основао Барбаросин унук, цар Фридрих II, преводиоци су убрзо пали под утицај Михајла Скота $(\mathrm{Scott})$, негда чувеног филозофа, алхемичара и чаробњака, кога је Данте сместио у свој књижевни Пакао (XX, 115). Преводећи с арапског забрањену Аристотелову Historia Animallum и пратеће Авероесове коментаре, Скоту је брзо пошло за руком да у Толеду, некадашњем римском Толетуму, окупи неке од најбољих преводила- 
ца епохе. Ту је, пре него што ће постати службени Фридрихов астролог у Палерму (1228-1235), основао тајну Апотеку преводилаиа. Рад ове апотеке оставио је дубок и трајан утицај на мисао наредних столећа. Најпознатији „апотекари” међу њима били су Самуел Сафир, секретар Алфонса X, и Герхард из Кремоне, који преводи низ Алкиндијевих расправа, а можда и Алфарабијево дело О интелекту. Предање о њиховом прегнућу, више аскетском него просветитељском, повезано је понегде с описима строгих ритуала и испаштања, тако да је настао цео венац митова, слика и ликова око тих предања.

Али мукотрпно превођење донело им је разне болести, а једна од њих је било „лудо око” или „журни поглед”. Била је то последица читања арапских текстова с десна на лево и њиховог превођења на латински у супротном смеру. Роберт из Честера и Герман Далматинац су се излечили од ове болести захваљујући златним трепавицама причвршћеним за десне углове очних капака. Повлачењем конца, трепавице би, попут спуштене завесе, усмеравале поглед у жељеном правцу. Али назив Апотека добила је ова гласовита преводилачка радионица пре свега захваљујући делотворном учинку ретких биљака, неопходних за концентрацију. Ретки су, уистину ретки, и они радознали ученици који су имали приступ њиховој тајној баштенској радионици. Чуло се неколико приговора, али они су остали без одјека. Суштина је, међутим, у следећем: недостатак речника и глосара потакао је ове апотекаре-преводиоце на узгој „језикословних биљака”, које су јачале меморију за арапски и хебрејски језик и егзотична халдејска наречја. Бадеми, микстуре и тинктуре, седење у кадама с миришљавим уљем, фармацеутски изуми језичких пилула од листова и корења ретких биљака - све је то повезало „душу и тело” преводилаца. 
Како то треба разумети? Какве то последице, не само симболичне или метафоричне, могу уопште произаћи из идеалистичке психосоматске доктрине која као резултат признаје само унутарњи спиритуални динамизам? Сводећи додир текста и тела на однос „разумске душе” и превода, показује се да делатни интелект можда није повезан са телом самим својим бићем, али јесте својим деловањем. Разумска душа и тело су једно in opere, quia in unum opus convenient, тврдио је париски професор из тринаестог века, Сигер из Брабанта, који је управо на томе заснивао читав свој наук. Отуда и чин превођења може бити приписан не само интелекту, него и целом човеку.

Али ево нечег још бољег. Један од најлепших примера идеалистичког виђења налазимо код Јозефа Хедриха, који се упустио у оштру критику некада славног италијанског државног филозофа Ђентилеа и притом рекао: преводилац може, на пример, своју непокретну руку да сматра за ствар. Али, то се сместа мења када се премишља, када полако узима перо у руку да запише одговарајућу реч. Ту за њега рука више није спољашња ствар, покрети руке су за њега у том случају истоветни с његовом вољом: није више могућно раздвојити његову вољу (тачније узето, његов душевни акт или себе) од покрета руке и писања. Тиме отпада дуализам између телесног и душевног. Преводити значи стварати себи тело, јер преводити значи мислити; мислити значи бити свестан себе; о себи, опет, немамо представе ако нисмо сами себи објекат, а тај објекат је наше тело.

Ђентиле наравно не предвиђа да би ово решење, беспрекорно у идеалистичкој теорији, у пракси могло и да се компликује. А разлог се увек може наћи у недовољном знању, у незаинтересованости или, просто, у подсвесном неслагању преводиоца са садржајем, односно aуторитетом текста. А то је већ проблем који се може 
сматрати кључним у решавању важнијег, начелног питања. Како се преводиочева слобода може помирити с ауторитетом текста? То јест, када он, ауторитет текста, постаје преводиочева слобода? Једино, могло би се већ сада рећи, када је она, слобода, исто што и дужност.

Апотекари-преводиоци су били свесни тога. Тачно је да су у својој башти гајили биљке, али са истом преданошћу су медитирали о својој филолошкој дужности и свом високом посланству. Њихово учење о преводу није доживљај светог Бернара који је над собом посматрао облаке и звезде, него доживљај човека који гледа кроз уске прозоре. Штавише, има више разлога да поверујемо како су апотекари-преводиоци себе сматрали једино аутентичним читаоцима оригиналног текста. И то у још већој мери него што су томе били дорасли његови критичари, а можда и сам аутор. Одломци, додуше, којима располажемо не допуштају нам да тврдимо да је то био пут који су следили и њихови наследници, али какви год да су извори ове приче, неке од славних доктрина и филозофских идеја, којима ће се и касније генерације инспирисати, зацело се могу наћи и у каснијим временима. Не само код Георга Хамана и неких европских романтичара, него и у неким савременим доктринама које тврде да је антитеза између материје и духа постала неодржива у светлу нових сазнања биологије, генетике и неуронауке, и које управо на бизарном односу текста и тела граде своје књижевне теорије.

3.

Превод и књижевна историја. - Омиљена је представа о преводиоцу који пати од својеврсног језичког едиповог комплекса, који своју духовну (очинску) мисију потискује силујући матерњи језик. Но није Едип 


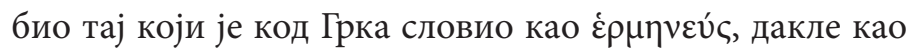
тумач, него митски Хермес, који се већ код Платона јавља у двоструком облику: као гласник који преводи загонетне поруке богова, и као рапсод који тумачи песничка дела. Стога му је на жртву био приношен језик. Ни оно што, на пример, Ортега и Гасет очекује од преводиоца није ништа друго него да сопствени језик жртвује на олтару једне ригорозно схваћене верности. Пледирајући за верност и тачност, а не за лепоту, он замишља идеалног преводиоца као научника опремљеног апаратом фуснота, коментара и објашњења.

Хладна тачност је већ у древној Александрији имала свој симбол у знаку пера - служило је као тег на ваги на којој се мере душе. Такав скрупулозни приступ не представља реткост ни у данашње дане. Када су Казуо Танака и Хироши Јамасаки Вукелић преводили Горски вијенаи, на јапански, пренели су епски десетерац на јапански четрнаестерац примењујући јапански језик средине 19. века, када је Његош и стварао. Али основни, најдубљи парадокс свога постојања превод не може да разреши. Преводе цене и процењују они који познају оригинал, дакле они којима превод није потребан.

Поводом превођења са кинеског и старојапанског на данашњи, савремени језик, јапански филолог Мотоори Норинага је инсистирао на истовременој креативној транслацији, то јест, на лексичкој и реченичној обнови која ће тако радикално, тако темељито унапредити (матерњи) јапански језик и књижевност да у њему - од сећања на негдашњи (кинески) изворник - неће остати ни трага. За страственог преводиоца Манових и Музилових романа, Јапанца Маруко Шухеја (Shuhei), то ће, међутим, представљати и највећи проблем - како да створи нови дискурс и тиме оживи и унапреди латентне могућности матерњег језика; како да, између 
осталог, преведе оне дуге, предуге немачке реченице на „језик на којем сањаш и на коме пишеш” - на језик који нема ни релативну реченицу.

Стога и поднаслов овога поглавља, Превод $u$ књижевна историја, који нас уводи у нешто дубље теоријске анализе, може изгледати необично, чак таутолошки, с обзиром на савремене теорије рецепције које управо на саморазумливом утицају превода изричито или имплицитно заснивају своја књижевноисторијска истраживања. Нагласак, међутим, овде лежи на томе да се оба појма, повезана, односно супротстављена у овој мање или више популарно третираној формулацији, прецизније одреде у смислу њихове спреге него што се то обично чини у практичној употреби књижевноисторијских разматрања.

Први, недовољно истражен феномен тиче се историјске дијалектике превода и његове одговорности за судбину књиге. Реч је о природи губитака што их је историји књижевности морао нанети изостанак праве и правовремене рецепције у ширим, светским оквирима - рецепције за коју су задужени преводи. То се поглавито односи на тзв. „романе идеја” срачунате на деловање у свом времену, дакле и на „писце свога времена и за своје време”, чије дело није било „дело будућности" и које зато није смело остати изоловано у своме времену, чекајући на бољи историјски тренутак. Јер бољег тренутка више неће бити: нова епоха донеће нове хуманистичке проблеме и тражиће им другачија решења, а ако је један део тих проблема, као што се сме веровати, остао исти, он he се у склопу новог битно изменити, те ће се и на понуђена стара решења нужно гледати другим очима.

Закаснелим преводом, испорученим за оцену и тумачење једној другој епохи у којој он више не може зна- 
чити исто, текст је изложен опасности да га за своје време безобзирно подиенимо, или да га за једно туђе олако - преценимо. Данашњој транслатологији тај проблем се намеће у својој херменеутичкој противречности. Јер, део тог проблема је само делимично разрешен племенитом намером „откривача” текста, који су, побуњени против такозваних објективних неповољних околности, настојали да врате његовој будућности оно што му је прошлост ускратила. Можда је за њих и посебно задовољство када виде како неко непознато „ремекдело” израња из тмине, тврдећи да су такорећи само и чекали на то. Из тезе да и наше време воли неправде које би саิмо могло исправљати, могло би се заједљиво закључити како истраживање ове врсте, измирујући свој дуг према преводилаштву, показује такву варијациону ширину и методу да би се смело посматрати и као умањена слика свеколике данашње науке о књижевности.

Међутим, већ самим тим што то изговарамо у уопштености ове појмовне формације, искрсавају и прве тешкоће, појављују се неодређености и непрецизности, које су садржане у традиционалном начину посматрања. Ако занемаримо саркастичну крилатицу 19. века, по којој је „песништво оно што се губи приликом превода", онда се оно што историја и општа свест схватају под појмом превода, наиме, преношење једног страног, уметнички већ уобличеног животног искуства или узорка света, не укључује, или бар не непосредно, у основно појмовно устројство синтагме песништво и стварност. Појам превода се онда, ступајући у конкурентски однос са стварношћу, појављује као нека друга врста инспиративног подстицаја или модела према којем књижевник ствара своје дело. Зависно од угла и функције посматрања, превод се појављује као стварност на квадрат, као мета-текст, као једна реалност, да- 
кле, која се удвостручује или која трансцендира своје емпиријско порекло, постајући својеврсна „поезија поезије”, како је то формулисао песник Новалис.

Па ипак се без индикатора односа према стварности не може одредити место превода према оригиналу. Иако је предуслов његовог постојања други текст, а не непосредно приказана стварност, превод не настаје само као одраз оригинала, као огледало другог огледала, него je, уједно, одређен и односом преводиоца као ствараоца према стварности. Посреди је заправо двоструки процес: први се успоставља према текстуалној онтологији дела које се преводи, а други према онтологији властитог искуственог комплекса који се неизоставно пројицира у текстуалној активности преводиочевој.

Јер сваки преводилац је интерпретатор: само преко њега се писмени знаци поново претварају у смисао. Као начин спровођења разумевања, филолошко превођење се, у својој суштини, приказује као херменеутички проблем, као посебан случај односа мишљења и говорења, у којем јаз који дели преводиоца од оригинала одговара разлици између језика неког текста и језика његовог тумача. Свако филолошко превођење је транслаторичка интерпретација, а свака интерпретација се развија у медијуму језика, језика који жели да омогући да предмет дође до речи, а који је ипак, истовремено, властити језик оног који преводи, а тиме и интерпретира.

Улога преводиоца, тачније: његовог језика, намеће стога један закључак који је великим делом запостављен у савременим моделима књижевне комуникације и у естетици рецепције: у филолошком превођењу није реч о пуком „прекодирању поруке”, о једноставном прелазу једног знаковног система у други. Смисао, додуше, мора остати, али пошто он мора бити схваћен у једном новом језичком свету, мора се и очитовати 
на нов начин у индивидуалном тумачењу преводиоца који репродукује и креира у исти мах. Слике, речи, метафоре, одавно излизане у једном језику, преводом обнављају свој првобитни рељеф, помажући језику коме су дошле у госте да буде живописнији.

Отресајући прашину са непрозирних опала архаичног вокабулара и доводећи до новог сјаја старе синтаксичке склопове, преводилац с друге стране увиђа нужност да се пипци превода пусте вековима у прошлост, али уводећи, у често погрешно схваћеној транслаторичкој слободи, читав низ неологизама, он несумљиво изневерава изворник, иако у рецепцији може - ето највећег парадокса - понекад измамити уздахе да је „бољи од оригинала”, па и попримити облике колективне фасцинације и када је реч о изворнику просечне вредности.

У односу на ову праксу улепшавања оригинала којој су се највише супротстављали управо угледни теоретичари превода у романтизму (браћа Шлегел), управо они којима је, иначе, до идеализације и улепшавања сваке врсте било највише стало - у историји превођења, наравно, није ништа мање честа супротна појава. Догађа се да особеност индивидуалног ауторовог стила, поетике, литерарног типа често може да осети тек друга генерација преводилаца, као у легендарном случају славног данског прозаисте Јенса Петера Јакобсена (Niels Lyhne, 1880), којег је Рилке држао „на столу поред Библије”, и којег је читао у оригиналу, јер му је „колевка била крај библиотеке”.

Испод сага заборава вреди зато извући и неке старе недоумице зарад лакшег одговора на таква питања. А да су та питања мука духу и трајни позив да се објасни накнадна актуелност текста на то подсећа једна необична слика. Преноси је Серен Кјеркегор, наводећи јед- 
ног немачког романтичара: „Оно о чему је Тарквиније Охоли разговарао, у својој башти, са главицом лука, то гласник није разумео, али његов син јесте”. Увид у овакве граничне случајеве погодан је за одбацивање погрешне, тачније: неисторијске романтизације преводиочевог статуса у историји књижевности, сагледаног у ванвременској представи ауторовог aler ego. Превод не постоји у апстрактном, неутралном идеалитету језика. Ниједан текст и ниједна књига не говоре ако не говоре језиком који достиже другог. Дијалектички корелатив чина писања је читање: књижевност је дефинисана вољом за даљим ширењем. Но, онај који преводи и даље шири, тај увек мисли и на своје сопствене савременике. Јер, будимо до краја прецизни: оно што je писмено фиксирано, одвојило се од контингенције свога порекла и свога ствараоца и позитивно се ослободило за нове односе. Појмови романтичарске херменеутике, као што су рекапитулација ауторовог мишљења или уживљавање у ситуацију првобитног читаоца (Шлајермахер), представљају заправо вакуум који се испуњава од једне ситуације читања и разумевања до друге. Историјски живот књижевности састоји се у упућености на стално нова усвајања и тумачења, у којима не доминира само однос према нечем изворно првом, већ и учешће у смислу сваке нове садашњости.

Па ипак је у романтизму најоштрије уочена дилема која заокупља све нововековне теорије превођења. Већ је Гете, у често цитираном говору посвећеном Виланду фебруара 1813. године, парафразирајући Цицеронову типологију превода (De oratore), установио две максиме за превођење, од којих једна захтева да се аутор неке друге нације пренесе к нама на начин да га можемо сматрати својим песником. Друга, пак, максима захтева од нас да се ми преселимо у расположења и језичке 
вредности и особености превођеног аутора. Његовом пријатељу Вилхелму Хумболту указало се слично разликовање у „овом великом столећу превођења”. Била је то визија у којој теорија постаје „нераздвојан пратилац” превода - „несносан и ненадокнадив” као Мефисто Фаусту.

Шлајермахер, који јуна исте године, у говору пред Краљевском академијом у Берлину (О методама превођена), допушта само другу могућност - јер прву, као својеврсни вид „натурализовања страног духа”, сматра немогућом, па чак и погубном - инсистира на томе да превод не сме да се чита као оригинал. Он мора да буде нека врста потуђень матерњег језика у циљу преношења у страну „атмосферу” и „менталитет”. Шлајермахер захтева доследно приближавање страном идиому, а та консеквентност фатално подсећа на напоре „логодедала", како је св. Јероним (De optimo genere interpretanda око 395. г.) иронично назвао поборнике дословног преношења смисла и такозване интерлинеарне верзије. Јероним, за кога „само преношење смисла има смисла” - осим у случају Светог писма где „већ и ред речи представља мистерију" - у чувеном Писму Памахију, упућено његовом пријатељу и доцнијем светитељу, упозоравао је на претеривања. Одбацио је манир Аквиле (Aquila), јеврејског прозелита који је, преводећи речи буквално, покушавао да заједно са њиховом етимологијом пренесе чак и исти број слогова.

Међутим, Шлајермахер, који - у вези са својим преводом Платона - први пут у историји херменеутике покушава да одреди опште законитости разумевања („Сваки превод значајног аутора истовремено је иманентни покушај његовог тумачења"), преводиоца ипак замишља као посредника који читаоца води само до границе сопственог језика. За Шлегела је, пак, fidus 
interpres, пре свега, дужан да при стапању личног и страног идиома верно пренесе - облик. Сасвим је очигледно: развој филологије и историјске свести извршио је утицај који се више није могао игнорисати.

Међутим, теорија је ретко када правило праксе. Као што Цицеронове напомене о превођењу нису имале никаквог утицаја на преводе грчких комедија у старом Риму, и као што у XVII веку, у виду неадекватне актуелизације у смислу познате преводилачке „лепе невернице" (belles infideles), Тукидид дожиљава својеврсну метемпсихозу, „сеобу душе”, постајући оно што не може бити: француски honnete homme, кога одликују урбаност, углађеност, љубазност и пуно галске свести о надмоћности, тако ће још у 20. веку остати на снази педантна и сувопарна филолошка дословност коју је забрањивао већ Цицерон: NON VERBUM E VERBO, SED SENSUM EXPRIMERE SENSU. Цео седамнаести век преводиоца сматра - књижевником. Тако се подиже фронт поклоника превођења, који умиру у нади да са сваким текстом граде универзалне лествице цивилизацијског напредовања. Но њихови слободни преводи не настају само с намером да се ослободе робовске зависности од оригинала, већ и у парадоксалној жељи да се буде сасвим свој. Сада је преводилац оригиналан, он није „слуга два господара”, изворника и дословног превода. Одатле та експанзивност, коју раније културе нису имале. Процес конституисања свести о превођењу конвергира с епохалним процесом формирања научне и историјске свести. Јер, степен историјске свести, коју одређена епоха поседује, може се, према Ничеовим речима у Веселој науии (\$83), „оценити управо према томе како та епоха преводи и како покушава себи да присаједини прошла времена и књиге”. 
4.

Изазови историје книжевности. - Шта, међутим, значи повезаност појмова „превод и књижевна историја"? Она подразумева двоје: да преведено дело не спада у интегралну историју неке националне књижевности, али и привидно супротно: да је преведено дело, као већ уобличени модел стварности, својеврсни подстицај, па чак и материјал песништва које припада некој другој књижевној традицији. Разлог што је ова околност тек у последње време постала стварни теоријски проблем, садржан је очигледно у томе што појмови превода и књижевне историје, онако како овде заједнички наступају, нису били подвргнути прецизнијој анализи значења. Појам превода, међутим, успоставља се у свом нипошто једнозначном смислу тек онда када се разјасни појам изворног песништва у свом односу према рецепцији стране књижевности - односу о којем је овде и реч.

Глобална рецепција Русоа, на пример, представља парадигматски случај општег односа традиције и изворности јер, тематизујући изворност, Русо, својом историјском појавом, у исти мах заснива једну традиицју изворности. Ретка су, међутим, времена у којима је естетска намера прожета изворношћу и оригиналношћу; она су пре изузетак него правило. Примери за „естетику истоветности” су фолклорна баштина свих народа, средњовековна књижевност, commedia dellarte, класицизам и бројне стилске формације, чију неминовну деканонизацију изнова канонизују епигонски следбеници.

Општост ове констатације доживљава нека карактеристична одступања, која је, међутим, индиректно потврђују. Постоји, при томе, једна форма ауторитета 
коју историја књижевности нарочито брани: аутохтона традиција. У деветнаестом веку, када је идеологија националних књижевности славила свој највећи тријумф верујући у супстанцијалну различитост, у различитост бића појединих књижевности, представа о генетској самосвојности следила је генералну линију романтичарских идеологема: да је књижевност, наиме, она историјска појава која идеји националне индивидуалности даје највиши израз. Ту идеологију додатно је појачавао увек актуелни страх од стране културне хегемоније, на који је, својевремено, упозоравао руски слависта Д. С. Лихачов. То је само још један од разлога због којих поредбено проучавање преводаิ, у првом реду литерарних, у сплету разноликих односа према суседним књижевним традицијама, има тако велику важност и за карактеристику суштине страних утицаја, њихових смена, њихових условљености одређеним друштвеним потребама.

Одмеравање нашег са страним, сопственог са туђим, аутохтоног с преузетим, увезеним, позајмљеним, читава та огромна, свеобухватна тема, назначена у наслову овог поглавља, насушно важна јуче, данас и сутра, могла би да буде сажето изложена у виду неколико кључних сентенци, са непобитним закључком да преводи представљају праоснов и залог властитог културног стварања, извесност будућих креација. Насупрот цивилизацији затварања и бежања од страног, теорија и пракса превођења - а за њом, боље рећи са њом, и читава легија преводилаца - листом су заговарале рецепцију страних дела, чак и они што су у изазовима страних идеала, односно модела и начина постојања, повремено хтели да препознају опасност за сопствену културу. Чувени манифест који је француска Академија наука, плашећи се за судбину своје цивилизације, 
објавила против немачког романтизма - тек је усамљен случај.

Никада се нећемо одрећи оног што је наше, аутентично, аутохтоно, уверава Гете у Вилхелму Мајстеру: „То је темељ сигурности појединца на чему се, у крајњој линији, гради кохерентност и достојанство целине", али у писму Томасу Карлајлу, 20.7.1827, поводом рецензије књиге German Romance, Гете не одустаје од концепта универзалности. Пожељна су, тако, сва „очигледна настојања најбољих песника свих нација", која се управљају према општељудском. Кроз сваку специфичност, сваку личну или националну особеност, свеједно да ли је историјски, митолошки, бајковито или мање-више за невољу дочарана, мора просијавати општост. Није, дакле, реч о безобзирном потискивању посебног зарад чисте општости, чак ни кад је реч о општељудском, напротив. Специфичности се спасавају - помоћу дијалектичког аргумента: „Морамо упознати особености сваке нације, тако што ћемо кроз прихватање саобраћати с њима; јер, својства нације су попут њеног језика и нумизматичке збирке. Она олакшавају саобраћање, штавише, она га тек чине могућим".

Да бисмо превели оријенталну поезију, морамо се оријентализирати: све друго би представљало отуђење од истине, каже даље Гете у Преласку тропа ка параболи. Говорећи пак о преводу Српских песама, он се сада обраћа елити, „образованој публици”, с упозорењем да није реч о „сентименталном усвајању ситуација које цивилизованом свету могу изгледати ексцентрично и тако постати извор задовољства неке посебне врсте. Не, ми захтевамо нешто друго. Треба да се осмелимо и пођемо у посету Србима на њиховом кршевитом тлу, и то тако као да се све догађа коју стотину година раније, и као да се догађа нама лично. Да нашу имагинацију учинимо 
раскошном, да је обогатимо овим ситуацијама (стањима), и да се оспособимо за слободнији суд о нама".

Драгоценим ће у том смислу сматрати превођење и Штефан Цвајг у свом Јучерашъем свету: „Баш услед тога што сваки страни језик, у својим личним обртима, испрва пружа отпор препевавању, он изазива изражајне снаге које, иначе, нетражене, не доспевају у употребу, и та борба да се страном језику упорно изнуди оно најсвојственије и да се једнако пластично укалупи у сопствени језик, увек је за мене значила нарочиту врсту уметничког уживања". Но ако је и сам Гете превођење одраније сматрао за „хвале вредан труд који нас уводи, привлачи и мами", онда је у поменутом писму Карлајлу још јасније подвукао његову преважну улогу, повезујући верско и меркантилно на начин који веома подсећа на Хегелов дискурс. Немци, по њему, већ дуже доприносе међусобном повезивању и уважавању. „На великој пијаци где све нације нуде своју робу, они су тумачи који се управо кроз тај медијум обогаћују”. У том светлу треба видети сваког преводиоца -„он је посредник у општој духовној размени".

Јер, шта год мислили о мањкавости превођења, каже Гете даље у истом писму, који год аргумент потезали, „превођење остаје једна од најчаснијих и најважнијих делатности на овом свету. Коран каже: 'Бог је сваком народу дао једног пророка на његовом сопственом језику'. И зато је преводилац пророк у свом народу". Ко би се усудио да овде допуни мисао „великог паганина” Гетеа? Верника изван догме и слова? И то једном сликом која потиче управо из хришћанског наука - мада би се некоме могла учинити натегнутом сва та узвишеност са њеним обећањем спасења, каква се, уосталом, открила и Павлу, юему јединоме, на путу за Дамаск: „Исус је Спаситељ, а Павле његов пророк”. Аналогија је 
допуштена јер нас много тога у исти мах подсећа и на слике из 1001 ноћи - најпре то што Бог са̂м бива затворен у речи и слова, па га позвани отпечате и приморају да се открије као истина.

Ту се сударају крај и почетак. Могло би се, наиме, наставити с тумачењем да је преводиочева реч део неког магијског процеса, који кроз њега добија „откривени” чулни облик у гласовима, а најпре у словима. Коран, уосталом, значи „читање”. Тиме је у најдубљем могућем смислу изражено оно што је касније основ појма и облика целокупне писмености. Ове су мисли већ биле најављене у поглављу Превођење у једном замашном конволуту Гетеових расправа (Noten und Abhandlungen zu besserem Verständnis des West-östlicher Diwan), али су сада нашле свој наставак у смелој тези да преводилац, у тој својој „размени”, не ради само за своју нацију, него и за „ону са чијег оригинала преводи”. Отуда су и односи између оригинала и превода управо они што „најјасније исказују све друге међусобне односе које нам поглавито ваља упознати и оценити у циљу подстицања светске књижевности".

Ова напомена нас преко проблема језика поново враћа на његов оглед о српским песмама (1824), у којима је осетио истовремено даљину и присутност као оно што чини да се прошлост и блискост стопе у јединство, и у којима се и сам осећао „проширеним” и - безвременим. У том огледу се, међутим, говори и о нечем другом. Немачком језику се овде приписује изузетна способност асимилације страних идиома, фраза и неологизама; немачки то чини без бојазни да ће му ико пребацити нешто бизарно или недозвољено; он се лако приближава свом пандану, страном језику и његовим звуцима, акцентима, а све то уједно незадрживо води „интензивирању преводилачких способности”, 
како нас Гете обавештава у својим скицама за оглед о Српским народним песмама (1826/7), бисеру у његовој круни. То је „мамац који наводи на учење немачког; не само због заслуга наше књижевности, већ да би постала у све већој мери посредник приликом уједињења свих литература".

У једном писму свом поштоваоцу, академику Боаcepey (Boisserée,24.4.1831), Гете последњи пут помиње синтагму светска књижевност. „Ових неколико главних места у мојим ботаничким радовима, које пријатељ Cope (Soret) није разумео, са̂м сам превео на мој француски; он их је опет вратио на свој, и тако ће, чврсто сам убеђен, бити на његовом језику још разумљивија него на немачком. Једној француској дами је тај трик наводно већ пошао за руком. Затражила је груби, неумивени, али разумљиви превод са немачког, а онда му дала љупку углађеност својствену њеном језику и родној припадности. То су непосредне последице светске књижевности”.

Али, понекад се овој идеји у доба романтизма, у време када је најпознатији вајмарски класик већ сишао са литерарне сцене, придруживао и један од најпарадоксалнијих критеријума у историји превођења - критеријум преводивости као вредносно мерило које је, додуше, одударало од истовремених теорија космополитизма и универзализма. Што тежи превод, то већи изазов, али и слава. Тако једна парадоксална формулација Жана Паула Рихтера износи тезу „да преводиво уметничко дело, дело које, се може превести, уопште не заслужује да буде преведено”.

Парадоксална формулација ове врсте, коју налазимо и код његовог савременика Ернеста Ренана, подстицајна и због тога што на духовит начин, у привидној противречности, указује на дубљи смисао. Реч је, на- 
просто, о томе да тешко преводива дела представљају користан језички изазов за националну културу, за језички осећај. Чак и онда када због сложености идиома измичу сваком покушају. Или кад се, на пример, обиље германизама и архаизама, који свакако доприносе неодољивом шарму у Сеобама Црњанског или у виртуозном кајкавском хибриду Крлежиног Керемпуха, опире њиховом превођењу на било који страни језик. Као што је песништво преображен свакодневни језик што открива односе за које не постоје готови изрази и мисаоно-синтаксичке везе; и као што филозофија не треба да буде ништа друго до непрестана ковница нових појмова - тако и превод даје нове појмовне ликове, ширећи и свесно мењајући значења речи.

Али у епохама словенских препорода, ствари су стајале нешто другачије. Као идеал им је лебдело пред очима управо оно што је Хердер забрањивао: „Ниједан човек, ниједна земља, ниједан народ, ниједна историја, ниједна држава не личи на друге: према томе, није једнако ни оно истинито, лепо и добро у њима. Ако се то не истражује, ако се слепо узима нека друга нација као модел, све се гуши". Данас нам се, међутим, у овом контексту једнако важним чини и ово: однос националне индивидуалности и космополитизма одражавао се на књижевном плану у тезама о језичкој посебности (пуризам), коју је ваљало обезбедити у првом реду „узорним преводима" истакнутих дела светске књижевности. Ови преводи - као што је то својевремено био случај у немачком просветитељству (Готшед) - имали су задатак да изграде литерарни укус, језичку изглачаност и осећање стила (Јунгман у Чешкој).

Наравно, пуко робовање страном идиому сматрано је за националну издају. Док би, насупрот томе, конгенијални препев у духу „нашег” језика, лако постајао до- 
маћи културни производ. У бројним „језичким друштвима" из доба барока, у жестоким сукобима између пуриста и новатора, упорно је понављано како се из најбољих превода могу извући стабилна правила за домаће стандарде. То су начела која се „дају угледањем присвојити” и према њима судити о другим делима. Вредност превода одређује значај који има општи културни развитак народа. „Садржајна изворност”, пак, замишљана је тек као друга фаза у развоју националне књижевне посебности. Био је то процес који у германском и словенском простору касни у односу на романски, процес који спутава вишејезичну лектиру, али поспешује и наличје - када се у настави језика читају текстови у оригиналу.

Преводи су, отуда, у првом реду представљали стилске ауторитете једне много више врсте. Они постављају на главу однос између језичке углачаности и књижевне мимезе. Реч је о енергично спроведеној лексичкој и стилској разбокорености као неопходној претпоставци сваког књижевног дела у естетском смислу. Али, предности таквог приступа истовремено су и недостаци. Тако се и могло догодити да поједини сегменти текста досегну висок стилски ниво, иако услед околности свог настанка нису могли да изграде и тоталитет савршенства уметничког дела. Тиме је, штавише, само продубљена она дилема која се провлачи кроз теоријске списе и преводилачку праксу све до данашњег дана - дилема која звучи као неки казуистички трик: приближавање страном идиому и његовом облику до границе коју матерњи језик може да поднесе, или превођење на начин да се страни аутор може сматрати домаћим писцем. А то, опет, само значи да преводилац има два избора: он ће се верно држати оригинала науштрб матерњег језика, или ће се огрешити о оригинал и остати веран особеностима свог језика. 
Чињеница је, ипак, да између традиције и иновације - не постоји безусловна супротност; чак и у временима историјских авангарди, у окриљу радикалних литерарних кретања, и тамо се, у тобожњој мени свих ствари и универзалне пријемчивости за страно и ново, очувава и са новим стапа много више старог него што се то обично слути. Тако су се форма и функција нововековне авангарде, након што су стигле у земље које се налазе на друкчијем ступњу књижевног и друштвеног развоја, помешале са тамо постојећим специфичним традицијама, понекад их чак и јачајући на шароликој филозофској и идеолошкој фасети: у румунском симболизму (Тудор Аргези) у фолклорној мађарској балади (Бела Балаш), у финској (Хелакоски) и грчкој новоавангарди. Овај паралелни ход са општом линијом књижевног развоја потиче, уосталом, још од њеног почетка, као што је то већ уочено на примеру француског надреализма.

Два екстремно супротна приступа феномену традиције, искристалисана теоријски у епохама просветитељства до романтизма, и формулисана у виду ванвременског обрасца, не би могла да реше овако постављен проблем. Јер и просветитељска критика традиције као „укалупљеног менталитета" и њена романтичарска рехабилитација као „уназад окренутог пророштва” (Новалис) заостају иза њене историјске суштине, чију тешко докучиву дијалектику оригиналности и опонашања, мимезе и имитације, покушава да одрази и једна парадоксална формулација Винкелманова: „Једини пут за нас да постанемо велики, па чак, ако је могуће, да постигнемо то да нас нико не може опонашати, јесте опонашање старих”. Површни читалац овакав став доживљава као стваралачку недоумицу или класицистичку заслепљеност; историчар књижевности у њему види 
духовни етимон епохе. Види га јасно и непогрешиво баш као што историчар уметности види у дуборезу дух реформације, а у бакрорезу дух рококоа.

Међутим, ни онај други приступ, онај који полази искључиво од чврсто укорењених тенденција у народним традицијама и фолклору, није ништа мање једностран. Као што национална књижевност, и поред велике улоге традиције, која се огледа у релативној постојаности аутономних литерарних родова, стилова, облика и мотива, није текстуални перпетум мобиле, тако није могуће ни бранити тезу да је њена историја резултат ендогеног процеса. Повест литерарне реторике није ни монокаузални одраз друштвених прилика, које су тек посредно седиментиране у смислу и у формалним категоријама уметничког дела, јер оно садржи како елементе баштине, који се могу на различите начине актуелизовати, тако и елементе негације постојећег.

Ни улога превода страних књижевности, у својој суштини, не изгледа много другачије. Свако истраживање склопа повезаности и утицаја мора поћи од принципијелног увида да његов примарни задатак није одређивање константних величина, већ поимање једног динамичног процеса, једног историјског развоја, у којем се токови деловања превода адаптирају зависно од времена и историјског места на којем налазе свој одраз у одговарајуће измењеним облицима. И овде, као и другде, уосталом, важи древно картезијанско гесло: „La nature de choses est bien plus aisée à concevoir lorsqu'on ne les considère que toutes faites". Традиција светске књижевности, као систем књижевних норми које условљавају идејно-естетску свест и очекивања читалаца, није нека објективно постојећа величина, није једном за свагда дат систем вредности унутар којег се све може упоређивати. 
Важну улогу играју при томе ванлитерарни моменти. Вергилије је у целом средњем веку био цењен због наводне хришћанске надахнутости (4. еклога), док је „пагански” писац Хомер тек у ренесанси стао испред њега. Захваљујући оваквим проценама, феномен литерарног канона, који се јавља од антике до данашњих уџбеника, представља значајно идеолошко поглавље историје књижевности. Не малих недоумица проузроковао је, а у неким расправама узрокује још увек, однос литерарног канона и вредносне норме одређене епохе. Тај однос одликује динамична напетост која се, у проблематици измене норме, хијерархијском померању, селекцији - а понекад и цензорским захватима - огледа углавном у два (често истовремена) вида: у виду рестауративног традиционализма који има апологетски однос према културној баштини, или у виду радикалне ликвидације сваке традиције литерарне прошлости у име будуће културе човечанства. У потоњем случају пледира се за превођење оних дела која одговарају актуелним аналогијама или антиципацијским визијама.

5.

Превод је оригинал. - Почев од 16. века, руска штампана црквена књига слата је у балканске земље Србима и Бугарима као оригинал за рукописне копије. Али је и међу католицима званични превод Библије, латинска Вулгата светог Јеронима, био проглашен за оригинал на Тридентском концилу. Наручен од стране папе Дамаскуса I и проглашен за једино аутентичан текст, аутоматски је ставио ван снаге изворне језике, хебрејски и грчки, док су на index librorum prohibitorum, објављен 1564. године, стављени и сви други преводи. Не само протестантски. Штавише, свако будуће превођење је 
било забрањено на овом, деветнаестом по реду, екуменском сабору Католичке цркве. И док је приликом преласка са старе словенске литургије према глагољским књигама на латинску - а пре него што ће Рим поново дозволити мису на народном језику - клер ипак настојао да за народ остави приступачним перикопе које читају на мисама, дотле је Шпанија је била једина земља која је указом забранила преводе свих библијских текстова на шпански језик. Судбина превода се показује у двоструком светлу: час као наличје медаље, час као други стожер - као биће које је исто толико моћно и кад самозатајно узмиче и кад активно дела.

То је један од већих парадокса у духовној историји. Јер, према великим таласима превођења могла би се пратити и делити целокупна духовна историја. А у њу, пре свега, спадају преводи Библије, почев од првог превода хебрејског Старог завета на грчки језик у III веку пре нове ере. За однос превода и историје књижевности највећу интеркултурну тежину имао је притом са̂м језичко-стилски трансфер. У бројним националним књижевностима рещепщија Библије је најбољи показатељ процеса духовног посредовања и језичко-књижевног сазревања. Тврдећи да ниједан превод Библије не може бити коначан, Јуџин Нида (Nida), гласовити баптистички свештеник и отац „динамичне еквиваленције”, захтевао је посебну синтаксу. Била би у функцији значења и изражајности говора са којом ће бити преведене библијске поруке, будући да су, у склопу нарочите реченичне интонације, више намењене слушању него читању.

Ретка су ипак времена у којима се, као што је то био случај са римским усвајањем старогрчке културне баштине - које је започело преводом Хомерове Одисеје (Ливије Андроник) у III веку пре Христа - може говорити о појави коју је својевремено, у изворном, 
свеобухватном смислу, означавао културолошки појам translatio. Такав је, на пример, био 12. век, класична епоха преводилачке историје, која је оксиденту приближила духовни свет арапског истока. Пад маварске власти у Шпанији отворио је пребогате библиотеке Толеда, открио је дела Авицене и Алфарабија; Петрус Венерабилис преводи Коран, Михајло Скот преводи коментаре о спису О небу и свету, Алпетрагијев спис $O$ лопти и Авиценин О животиғама; Аделард Бат преводи арапску верзију Еуклида.

Након тога уследио је период окретања изворима, период директног превођења са грчког језика, а тиме и ново поглавље филозофске, политичке и социјалне мисли у Европи. Два значајна резултата исламског духовног посредовања била су схоластичка филозофија, оријентисана на Аристотела, и настанак европских универзитета. Аристотелизам, међутим, био је преузет заједно са коментарима и њиховим снажно неоллатоновски обојеним схватањима, која у средњовековној науци омогућавају процват мистике као својеврсне протутеже схоластици, што ће касније наћи одраз у раздвајању теологије и филозофије.

Стваралачко значење превода у овој епохи састоји се у ширењу могућности апстрактног изражавања. Тако је Мастер Екарт, отац немачке мистике, који је схоластички интелектуализам развио до хетеродоксије једне идеалистичке мистике, сковао термине без којих се проза немачке мистике не може замислити. Пре свега, на плану апстрактног вокабулара, чија фасцинација просијава у низу необичних слика, смелих метафора, симбола и других тропа. Свестан колико је сваки велики појмовни апарат уникатан, изузетан, једнако као што и његов одраз и адекват мора бити, Екарт их уноси свесно, како би оштру појмовност и спекулативну снагу своје мисли прилагодио изворнику. Иако 
су његови неологизми срочени према шаблону који су нудила граматичка и реторичка правила схоластике, његова спекулативна мистика представља, по општем мишљењу, прву велику лексичку катарзу из које је произашао одуховљени немачки језик.

„Ехо” је, тако, одјек једног гласа који се не може чути. Екартово посматрање следи парадоксе физике и оптике. Будући да „мисли нису плодови земље”, мисао о Богу је „психолошка вредност”, како је протумачио Карл Јунг. По Екарту се интроспекција одвија у „оку срца”, док је васиона „слика ствари које се међусобно зрцале”, али не фиксирају, ширећи нашу моћ представљања. Речи светих изворника су ланци којима недостаје први беочуг; душа тражи субјекат који све сједињује, а то је Бог. У речима превода, пак, душа тражи објект који сједињује, а то је преводилац.

Теорија превода се не може једноставно апстраховати из његове историје, јер ова битно доприноси њеном објашњењу, утолико пре што се и сама теорија историјски развија. Тако одушевљавање антиком - „извором свих сазнања у апсолутном смислу” - у италијанском и француском хуманизму резултира значајним теоријским разматрањима. Леонардо Бруни из Фиренце, најпознатији преводилац хуманистичког кватрочента, већ је 1440. године, дакле, пре Лутера, створио једну општу литерарну теорију превођења која укључује и профане текстове (De interpretatione recta). Тек је након тога био извршен покушај синтезе теорије патристике, везане за Свето писмо, са профаном теоријом хуманиста (Huetus). Са Брунијем се завршава прагматична фаза средњовековног превођења, које је пред собом имало јасан дидактички циљ: приближити образованом слоју фактички-корисна, употребљива знања.

Интелектуална култура антике, коју су кроз сукцесивно примање античке образовне грађе припре- 
мали средњовековни полихистори у циљу васпитања европских народа, уливала се у бројне енциклопедије и компендије, замишљене као ризнице тзв. „здравих мисли", анегдота, dicta et facta, а педагошки, моралистички и политички коментари преведених дела проширују се почев од ренесансе у самосвојни књижевни облик који се скоро неприметно уклапа у афористичку и есејистичку литературу епохе.

Видели смо да на почетку нове фазе историје превођења стоји Мартин Лутер. Међутим, ако је Лутер, у чувеном делу Sendbrief vom Dolmetschen (1530), захтевао напуштање учене високопарности израза и примереност језика, с обзиром на публику, онда је француска ренесанса, чии су преводиоци кренули истим или сличним путевима, претворила преводилачку еманципацију језика у тзв. рђаву бесконачност.

То је представљало и својеврсну издају идеја тзв. Високе ренесансе. А њих је заступао и један Албрехт Дирер, опседнут ренесансном идејом о превођењу као трансферу знања. На сваком од три мајсторска бакрореза на којима је приказана сцена превођена св. Јеронима, посебно на оном из 1514. године, ликовна симболика је сугерисала посве другачију атмосферу у којој доминиpajy: прво, верност и концентрисана посвећеност тексту; друго, симбол захвалног лава коме је Јероним извукао трн из шапе; треће, слика пса који спава, и четврто, пешчаник из којег као да разговетно сипи време.

Насупрот томе, слободни ренесансни преводи (Клеман Маро, Ди Беле, Амио), за које се више нипошто не може рећи да код њих „ред речи представља мистерију” као код Јеронима или Августина, не могу се правилно схватити без увида у феномен хуманистичке imitatio, a она се, опет, мора схватити у светлу тзв. империјалне језичке мисли. Ова мисао је, наиме, доминирала епохом, пре свега у Француској, у којој је најдубље продрла 
свест о томе да Рим за свој светски значај захваљује не само оружју него и (латинском) језику. „Мач и перо” та империјална синтагма претворила је приватну преводилачку активност у националну ствар, чији задатак је да све што је страно натурализује, а све што је старо - консеквентно модернизује.

Као илустрација борбе за језичку превласт често се препричава следећи догађај: на изазов Анрија Естјена (Estienne), који је у духу „национално надахнутог језикословља" тврдио да италијански језик није способан да пренесе са истом прегнантношћу текст какав је на пример Тацитусов, одговорио је Фирентинац Бернардо Даванцати (1529-1606), који је својим чувеним Tacito Fiorentino доказао минималистички кредо - „мање је више”. Овај полихистор и члан тамошње учене академије, сачинио је један превод Тацита in lingua fiorentina propria, чији обим је мањи од оригинала.

Али управо тамо где се хуманистички преводилац служи и латинским и својим матерњим језиком, показује се велика разлика - како у намери тако и у последицама. Сва естетичка и научна стремљења магнетски је привлачио латински језик као језик с великом духовном традицијом освештане образованости. С правом је, међутим, запажено: када је, на пример, борбени протестант Хутен своје дијалоге превео на немачки, он више није био хуманист, него национални агитатор.

С друге стране, када је реч о последицама, од Лутеровог превода Светих списа учврстило се Хердерово мишљење да је „он био тај који је немачки језик, заспалог дива, пробудио и одрешио”. Од њега је потекло национално уједињење помоћу језика, а тиме и одређена цивилизацијска надградња на импулсима настајуће коине - једног наддијалекатског, релативно хомогеног књижевног идиома, који ће тек доцније бити прихваћен као симбол националног идентитета. Попут Вуковог доприноса или Ки- 
риловог превода Четворојеванђеља у Моравској, тако су слични језички творци многим народима отворили врата у храм светске културе. Нарочито корисним се може означити сваки онај допринос који је, у духу принципа прокламованих у Франиуском оратору контроверзног Етјена Долеа (E. Dolet, 1540), тежио да, преводећи с већег на мањи језик, развија мање развијен језик.

У ватромету његових идеја најпре пада у очи хуманистичка мисао која користи двоструки регистар. Иако је Венецијански Елени писао љубавне песме на латинским Доле је елитизам сматрао за патологију комуникације. Пре него што ће бити задављен и потом, јавно, заједно с омиљеним књигама, спаљен на ломачи, овај страствени заговорник „превођења по сваку цену” видео је у њему средство обнове и развоја човечанства. Видео је културу размене, културу слободе мишљења у неслободним временима. Видео је нову младост, динамичност, ширење и победу знања.

И рецепција поезије путем превода имала је у хуманизму чудну судбину. „Петрарка је био генијалан”, рећи ће Еразмо, „али га више нико не чита”. Драстичних разлика има и на другој страни. Ако је историја превода у XVI веку у битној мери историја превода са старих језика, онда се у XVIII веку све више јављају преводи са италијанског и шпанског, при чему француски служи као подлога за даље превођење на енглески и немачки. Духовна клима коју је донела француска књижевност, била је веома повољна и за напредовање естетичких расправа и преводилачких доктрина. У току овог века продиру и први енглески текстови на француско подручје, на којем - све до завршетка тзв. Ancien régimea - кулминирају рецепцијом Шекспирових дела.

Али схватање, на пример, да има нечег суштински варварског у сваком Енглезу, укључујући Шекспира, 
и нарочито Шекспира, није само опште место у историји галског духа. Оно се успешно одржавало и код других, све до Волтерових дана, када је његовог пријатеља пруског краља Фридриха II чудило да нема више неправилности у Јулију Цезару с обзиром на то „ко је уопште писао" тај комад. Тај човек не зна где је Илирија и да Чешка нема море! Да парадокс буде већи, он, Фридрих Други, који се на немачком језику споразумевао само са коњима и псима, написао је на француском једну Историју немачке књижевности! С друге стране, пак, шта о француском „цивилизованом пренемагању” мисле просвећени представници других народа, речито говоре читаве библиотеке ироничних игроказа, читава једна традиција поруге и неразумевања.

Но и даље се може говорити о одређеном континуитету облика и технике превођења. Оно што, на пример, књижевност француске класике одваја од одлучно негиране познохуманистичке прошлости, јесте само једна рационалнија контрола оног истог принципа подражавања антике, који је био заснован и, у исти мах, хипостазиран у хуманизму, односно ренесанси.

Не треба изгубити из вида да је, и у том времену интензивне духовне размене, превођење било сасвим изједначено с уметничком креацијом. Већ је Вида из Кремоне (1507-1566) изричито говорио:

Haud minor est aleo vitus si te audit Apollo Inverit Argivum in patrian connectere vocem

Quam si tute aliquid intactum inveneris ante ${ }^{2}$.

2 Cit. prema: Joel Elias Spingarn, A history of Literary Criticism in the Reaissance, New York 1899, p. 133. 
Очигледан је чак и модернизам чији се утицај осећа у преводилачкој пракси, иако она коригује антички оригинал тек у имплицитној свести властите културне надмоћи. Парафраза се посвуда разуме сама по себи (Опиц у Немачкој, Малерб у Француској); за Енглеза Драјдена (J. Dryden) апологија слободног превода оснажена је појмовима: „метафраза”, „парафраза” и „имитација”.

У веку разума, у епохи за коју су речи биле само „знаци за мисли”, како је тврдио просветитељ Волф (1679-1754), теоријско питање превођења није се постављало као нерешиво. Напротив: идеја заједничког језика и принципијелне преводивости свега, која је заокупљала Лока, навела је и Декарта да поред једне Mathesis universalis захтева и једну Lingua universalis. Представа, наиме, да постоји нека дубока укотвљеност језика у јединству људског разума, иницирала је разноврсне системе вештачких, општеразумљивих језика. Превод је већ тада био замишљан као пука математичка операција, као прелаз једног знаковног система у други (данас: A. G. Oettinger), или као укрштање фиктивне једначине оригинал=превод. Декарт је, на пример, тврдио да је и људско тело машина. И док је Дидро сматрао механику и хидраулику најважнијим наукама јер наводе на проучавање анатомије човековог тела - те најлепше машине која се битно разликује од рђаве машине, Бога -, дотле је Молијер ту механичку психологију драматизовао на позорници. Није отуда необично ни то што су вршени покушаји програмирања за механичко превођење, који претходе модерним идејама машинског превођења.

Један чаробни мали бакрорез из 1661. године показује типичан барокни лик са бујном allonge-власуљом - лик Лоакима Бехера (J. J. Becher), угледног научника, чији долазак у Хановер је спречио моћни Лајбниц. Мла- 
ди Бехер је већ тада саставио један латински вокабулар (Character, pro notitia Linguorum Universali), који је преко нумеричког система био повезан с различитим граматичким категоријама. Све је, чинило се, било спремно за стварање једне просветитељске теорије превођења која би ставила завршну тачку на тежње ка апсолутној верности (Breitinger), и тако засела на престо централног принципа. У суштини је, међутим, представљала само далеки ехо популаризованог Лајбницовог појма језика.

Одвећ педантни псеудокласициста Готшед, склон сваковрсним доктринама, теорији аксиоматског, беспоговорног карактера, одредио је, на пример, седам тачака којих се преводилац мора стриктно придржавати. Њихова присила би, сигуран је Готшед, представљала „добродошло ограничење и удобну тамницу” за преводиоца као отвореног, ка бескрају устремљеног бића. Етичка пракса просветитељског доба извукла је из тога закључак да помоћу разумног расуђивања није достижна само истина сазнања већ и моралног деловања. Отуда налог да се разликује рђав од доброг превода. Додуше, у немачком позном просветитељству, ствари су стајале сасвим другачије, иако теоријске расправе, веома дуге и веома проницљиве - као на пример оне између J. Ј. Душа и Г. Е. Лесинга - нису оставиле никаквог трага на плиму „комерцијалних” превода.

Напротив: од епохе хуманизма - са првим значајним преводима Целестине (1520. и 1534), Лазарила (1614) и Дон Кихота (1648) - па до позног XVIII века, дневни критичари су и даље хвалили слободне преводе као „нова остварења” немачког језика, која битно доприносе унапређењу стилских могућности. Сваки нови превод поздрављан је као нови степеник на кривудавом путу усавршавања морфолошких могућности. У 
Француској је вишевековна традиција тзв. belles infidels дефинитивно прекинута тек са Шатобријановим преводом Милтоновог Изгубленог раја (1836). Али је утицај ових превода на развој националних књижевности био - огроман. Без њих се не би могао замислити успон европског пикарског романа, који прибегава пародији витешких, каваљерских облика ренесансне куртоазије, па ни доцнији развој европског реализма.

Стварајући нову основу за своја чувена учења о генију, епоха штурм-унд-дранга у потпуности напушта теорије превођења каква је, на пример, Хаманова, поготово оне које визирају превод са становишта критике или педагошке намере. Негирајући просветитељску теорију подражавања, која је одређивала теорију превођења све до Лесинга, ова књижевна револуција је доказивала немогућност спекулативне метафизике проистекле из способности разума.

Било је више разлога због којих је Фихте назвао Канта „трочетвртинском главом”. Кантовска и романтичарска критика чистог ума дискредитује и рационалну основу сваке теорије превођења. Немерљива, субјективистичка, ирационална заснованост оригиналног дела мора да остане у оквирима сопствених, а не дидактичких законитости. У још једном погледу није било никакве дилеме: прави, уметнички текст је преживети и аутора и његовог преводиоца. Зато је, рећи ће Бењамин, порастао степен верности оригиналу. Како год на то гледали данас, сувишним, ако не и смешним чиниле су се тада педагошки инспирисане интервенције на тексту.

6.

Геопоетика и геополитика превода. - Новим естетским представама уметничког апсолута одговарају 
Шлајермахерове, Гетеове, Новалисове и Шлегелове поставке, а њихови преводи (Хелдерлинов Пиндар, Шлајермахеров Платон, Шлегелов „наш” Шекспир, али и Тиков Сервантес и Грисов Калдерон) у исти мах одговарају тадашњој визији светске кюижевности, која се, „као из дубине огледала, бескрајно умножава, ношена луком небеског свода" (Менделсон). Она ће зацело потрајати дуже од сећања на наслов патетичне Фрајлигратове песме: Немачка је Хамлет (1844).

Шире се видици, говори о културној размени и новом, вишенационалном књижевном здању. У песништву се препознаје изоморфни отисак стране културе, њени знаковни системи, и многи други наноси, сложени у дубини књижевне речи. Импресивних примера има и на Далеком истоку. Јапански језик је, тако, преузео велики број фраза из кинеског, заједно с очекиваним семантичким померањем (фразеологизми, стереотипи, рутинске формуле), иза којег стоји друга конотација, другачија слика. Док је у јапанском језику идиоматска фраза „трљати руке” знак понизности или задовољства трговца због успешно завршеног посла, дотле та иста фраза у европским језицима означава радовање или олакшање. Као што различити језици имају различите појмовне системе, тако и жанровски различите врсте текста имају различите културолошке матрице.

Може се слободно рећи да је целокупно обликовање средњоевропске литерарне сцене протицало у знаку превода: Шамполион је решио загонетку хијероглифа. Гротефенд је одгонетнуо клинасто писмо. Шлегел је иницирао изучавање санскрита и азијске митологије. Напуштена је доктрина по којој су највећа дела створена у „властитом племену”. За књижевну историју су од највеће важности била открића древних записа, састављање збирки мудрости из класичне старине, епи- 
графских зборника, едиције „извора”. Преводи су дефинитивно искорачили из педагошко-позитивистичке филологије. Утицали су на формирање стила, али и на промену књижевно-језичке норме. Гете је, на врхунцу славе, објавио Западно-источни диван (1819) - један од највећих версификатора у историји успоставио је јаке стилско-мотивске везе с оријенталним традицијама.

Писци су тражили јединственост тренутка, откривали су магична расположења далеких и страних култура, у којима се животно осећање, крцато искуством и приправно за бесконачно прихватање, сажима као занос и бол. Налазили су естетску чар историје и старих песника, праскозорја давних доба или мудрост Индије. Колико је само Рикертова Мудрост брамана (1851), обухватајући преко три хиљаде изрека у стиху, персијског, хебрејског, арапског и етиопског, помогли у прилагођавању страним облицима као што су газеле.

Са напуштањем европоцентричних теорија „обрађивања сопственог врта”, као да се радикално мења и штошта друго: геопоетика и геополитика превода. Поетика превода не добија само вертикалну историјску пројекцију. У њој неминовно искрсавају запањујуће хоризонталне паралеле и аналогије са географски удаљеним културним круговима. Оне нису мање важне од помодних интеркултуралних феномена „разлике”, „другости” или „страности”. Контрастивне анализе показују да је европски романтизам, у склопу своје опште филозофије, развијао нарочиту филозофију превода (Ф. Шлегел) у исто време када су херменеутичке рефлексије чувеног јапанског филолога Мотоори Норинаге (17301801) - на основу дубоких естетичких и етичких увида у пролазност и пропадивост света (естетика туге - топо no aware) - раскривале смисао превода помоћу категорија саморазумевана, осећајности и исконског нагона. 
То је радикална филозофија превода у својој есенцији. Мада писана у другом контексту, поводом превода с кинеског, сви теоријски мотиви романтичарског мисаоног круга могу се наћи у систему Норинагине филолошке науке - теорија превођења, контрастивна анализа, теорија читања, поистовећење филологије и светоназора, историзација разумевања, тумачење страног текста и језика као аутономног бивства. Један од термина који описују доживљај текста је патос живота. Он изазива осећај емпатије и меланхолије - не само у животу, где је све ионако пролазно, крхко и случајно, него и у песништву, у естетици, где означава пролазност емоционалних елемената у уметничком делу.

У самом чину превођења одвија се својеврсни транфер појмова. Појам топо по aware је сада пренет из природе на уживљавање у један други предмет - у предмет превођења. И као што универзалну истину, каже Норинага, препознају само они који имају испуњен живот налазећи задовољство у малим стварима у природи, тако и преводиоци поседују дубоко, емпатичко разумевање текста. Оно што уметник чини несвесно стварајући свој имагинарни свет, преводилац чини потпуно свесно. Још прецизније: оно што уметник чини - а да то и не зна - у мрачној собици подсвести, чини и преводилац на даљем светлу своје самосвести.

У томе је суштина геопоетике превода. Са сопственим наслеђем као праосновом културног стварања, али и са драгоценим изазовима страних књижевних норми и вредности које су у истој мери представљале извор заједничке духовности, у Европи се још интензивније трагало за колевком саборне цивилизацијске пуноће која ће, у духу и стилу једне епски стилизоване приче, уједно понудити визију вечног обнављања.

Додуше, много пре Вика или Ничеа, али заједно са другим мислиоцима епохе, Сигер из Брабанта је већ у 
средњем веку развијао теорију о вечном повратку у новом светлу. Довољно је само летимично погледати овај програм да бисмо се обавестили о томе да идеја светске књижевности није престала да делује на целокупни развој доцнијих преводилачких доктрина. Захваљујући Хердеровом разликовању језичких „животних доба”, први пут долази до теоријског раздвајаға превода са старих и модерних језика. Тај феномен ће остати необјашњив све док се на превођење, сагласно средњовековним представама, буде гледало као на помоћно средство, као што ће, уосталом, и целокупна филологија, заједно са филозофијом, све до 19. века бити само „слушкиња теологије”. Али са овим важним Хердеровим методолошким диференцирањем било је дефинитивно прихваћено и Брунијево мишљење да преводилац није ни научник, ни занатлија, него уметник.

У деветнаестом веку долази и до кристализације различитих приступа проблему превођења. Најављујући савремене дискусије о родним поделама, социолог културе Георг Зимел је извршио својеврсну „климатску” поделу у области креативних предиспозиција. Жене се, каже овај гласовити филозоф, у принципу лакше крећу у емотивним, топлим пределима, с ону страну ледене пустиње у којој је мушки, то јест, стваралачки интелект, изложен оштрим олујама духа. Песнику Хаднеу је, опет, поменута женска природа послужила за дифамирање Шлегеловог талента: што бољи превод, то женственија природа преводиоца који је лишен аутентичне инспирације, импулса, интуиције мање вичан маскулином песништву из прве руке.

С друге стране посматрано, средином века у средишту занимања нашао се управо сам преводилац, човек са својим симпатијама, страстима, навикама, човек „попут оног којег смо управо видели на улици”. Тенова 
психологија текста постала је зависна од психологије преводиоца - преводилац је постао ауторов лични секретар. Но, ако за личне секретаре и собаре не постоје јунаци, како гласи стара изрека, онда је преводилац постао собар ауторовог идејног света. С друге стране гледано, књижевно-естетски појам преводивости, који није ни приватни ни антрополошки, који се позива на формалне елементе, као и онај други, лингвистички појам преводивости, који има у виду садржајно преношење језички условљених слика света, нашли су свој класични одраз у кореспонденцији између Хумболта и Шлегела. Њихове мале расправе о методи постале су легендарне.

И мада се теоретска размишљања у њиховом веку крећу од скепсе према дословности (Јакоб Грим), до бројних похвала верности и прозних превода поезије (Гете), за читаву немачку романтику, посебно за њену „прогресивну универзалну поезију”, све је у принципу преносиво и преводиво. О томе не сведочи само изузетно велики број превода, „секундарног оригинала” (огледало, резонанса, ехо, травестија, полеђина гоблена или тепиха, метемпсихоза, пловидба на другу обалу). И данас их још срећемо, како у похвалним рецензијама превода, тако и у критици целог преводилачког сталежа. У једној од кључних сцена Сервантесовог Дон Кихота, ови топоси су имали појачану сликовност: „Упркос свему, чини се да код превођења с једног језика на други (....) ствари изгледају као да посматрамо позадину фламанских таписерија; ликови се додуше на њима разазнају, али су изобличени мноштвом нити, и ми их не видимо у свежини боја као на предњој страни”. Истини на вољу, постојала су времена када су драматичној легенди о „ужасном убијању оригинала” супротстављани емпатични хвалоспеви. У стиховима 
нобеловца Јарослава Сајферта посвећеним епицентру прашке културе (Café Slavia, 1967), једном од симбола тзв. чешке авангарде описаном у Сајфертовим мемоарима Све лепоте овог света, искрсава лик Гијома Аполинера. У поетској епифанији „провидности”, превод постаје персонификација Лепог: „Кроз тајна врата према кеју,/ од тако провидног стакла да су скоро невидлива / ступио је Гијом Аполинер. / Од рата је носио повез око главе. / Сео је крај нас и читао стихове бруталне лепоте, / које би Карел Тајге сместа преводио". Поучна је, наравно, била већ и сцена у једном од најпознатијих романа из епохе романтизма. У књизи Годви или камена слика мајке Клеменса Брентана, главни јунак узвикује емфатично и само наизглед немотивисано: „Романтика - то је превођење".

Нововековни искази о превођењу, као теоријска рефлексија о пракси, сведоче о томе да новија историја теорије превођења не показује распознатљив след напредовања. Они који су постављали правила превођења најчешће нису познавали доприносе претходника. Лепеза тумачења је веома широка и у њој су могуће неочекиване унакрсне повезаности и подударности. Тако се метафизичка тумачења младог Валтера Бењамина приближавају просветитељским рационалистичким уверењима (Th. Huber). Истина, која је за Бењамина иманентна језичком уметничком делу, одређује уједно формалну страну преводивости, а она је управо та која омогућава принципијелну „преносивост”, садржану у сродности свих језика, јер истина у њима мора бити изражена у одређеном облику.

И Валтер Бењамин и Иво Андрић дозвољавали су дословност само у погледу синтаксе, а не и реченице, јер она је нека врста „аркаде” (Бењамин), односно „моста” (Андрић). Обојици писаца је пошло за руком 
да се из сасвим независне позиције вину на крилима властите спекулације у висине са којих је било могуће сагледати предности и пропусте читаве дотадашње теорије књижевног превођења. Андрићев омиљени симбол моста јавља се и у једном запису са скупа у Загребу (О преводиоцима и тумачима, 1949): „Ако су склони размишљању, код њих поред технике и професионалне ревности, мора да се развије и осећање релативности ствари и нарочита филозофија човека тумача и посредника, човека који стално обојици противника гледа у карте, који све гледа и све зна, али ни у чему не учествује и ништа не види и не може, и ништа неће, јер је само нека врста моста којим се сви подједнако служе, а који ипак остаје издвојен и свој”.

И ту смо, дакле, аркада, мост. Обе слике нуде метафору хегеловског укидања границе - дијалектичку категорију „прелаза”. Међутим, почев од Бењаминовог тумачења превода (као оног што представља tertium comarationis људског уопште), па до Блохове Филозоøије превода, која преко архетипских сродности уочава у „људском духу” једну „мета-синтаксу што повезује седамдесет и два језичка стабла”, све савремене филозофије превода указују и на удео ирационалног елемента у језику, на који, опет, упућују и неочекивани резултати електронских превода (W. Wills). Историја и теорија књижевности у све већој мери препуштају теорију превода лингвистици, анализирајући учинак превода у оквирима књижевне рецепције и упоредних истраживања дискурса. Па и сама филозофија књижевности, уколико је желела бити филозофија превода, одувек је била филозофија језика. У отискивању од двоструке опасности - с једне стране од методолошког насиља с унапред препарираном појмовном апаратуром и, с друге, од сентименталистичке идентификације 
с узвишеним и племенитим чином превођења - таква филозофија настоји да се не удаљава од песништва, да не буде „сива”.

А да теорија уопште није сива, већ да за сваку уметност обезбеђује широке видике слободе, било је јасно и билингвалном Херберту Бауеру, који ће под својим nom-de-plume постати славом овенчани теоретичар медија - Бела Балаш. Она је, каже у својој књизи Видљиви човек из 1924. године, „мапа за путника по царству уметности", која показује све путеве и могућности, а оно што је изгледало као неминовност, разоткрива као случајни пут између стотина других. Теорија је оно што даје храбрости за Колумбова путовања и што сваки корак чини актом слободног избора.

Овакав став према теорији био је, разуме се, карактеристичан за све чланове легендарног будимпештанског Недељног кружока, у коме су били и Ђерђ Лукач, Арнолд Хаузер и Карл Манхајм. Посматрана кроз преломљену критичку призму, крилатица о нади постала је омиљена у предвечерје Великог рата, када су, поред егзистенцијалних, улагане и нарочите наде у радикалну промену карактера теоријских разматрања: свако неповерење према теорији је сувишно, а сувишно је и питање какве појмове теорија иницира, какве фигуре мишљења провоцира. Пресудно је да буде активистичка, да спознаје, увиђа и усмерава. „Не мора уопште да буде тачна" да би инспирисала велика дела, тврдио је Бергсонов и Зимелов студент Балаш. „Скоро сва велика открића су пошла од погрешне хипотезе. Погрешна теорија се, осим тога, лако може одстранити када више не буде функционисала, док практична искуства случаја блокирају пут као дебели зидови”. Никада још, каже писац Видљивог човека, ниједна уметност није постала велика без теорије. А ту, разуме се, бледе сви покушаји 
који теорију превођења проглашавају за пуки конструкт, за духовну моду и плод површног фабулирања.

\section{7.}

Рецепиија превода. - Виктор Шкловски је својевремено известио о томе да Јапанце, када су добили први превод Толстојевог Воскрсења, уопште није шокирала чињеница да је Катјуша Маслова проститутка. Чудиле су их одговарајуће душевне муке Дмитрија Ивановича Нехљудова. И док је роман дао повода реакционарним круговима у Русији да Толстој буде екскомунициран из православне цркве, његов одјек у Јапану је изгледао сасвим другачије. Штавише, име Катјуша је у Земљи излазећег сунца од тог тренутка отеловљавало љубав као такву. Ефекат на који је роман наишао код јапанске публике сигурно није био онај који је Толстој намеравао да изазове, иако би се таквом тумачењу можда радовао.

Оригинални књижевни текст је хијероглиф који на јединствен начин повезује менталитет, историју и географију - али се ни тај оригинални текст не чита истим очима у свим временима. Шта тек онда рећи за превод, који треба да приближи уметнички текст некој удаљеној, страној култури, и то превод који је, понекад, толико успешан да се може оцењивати као самостално уметничко дело, заборављајући, макар и за тренутак, да је оно настало приликом превођења, а да се притом ни оно не може свести на заједнички рецепторски именитељ.

Нас, међутим, у највећој мери занима стваралачка рецепција, дакле, она суптилнија страна присуства превода у стваралаштву националних књижевности, начин његовог усвајања у интегрални део фикционалних текстова друге књижевне историје, критеријум избора из опсежног корпуса страних књижевности, 
степен модификације преузетих идеја и стилских средстава, као и функционалност таквих промена.

Оно што се никада не може превести, то је утицај који је оригинално дело извршило на сопствени језик - то је његова историја; језичка употреба преводиоца нужно стоји у односу који се разликује од оног у којем се налазио преведени аутор. Слабости и мане које се налазе у преводу нису увек слабости и мане изворника; назад, превод ни издалека није тако дугог века као оригинал: транспоновање једног језика у други подлеже језичко-стилским променама о којима одлучују различита историјска тумачења, произишла из разноврсних категорија пријемчивости. Односи између националних књижевности су веома стари, веома разноврсни и - веома асиметрични. Отуда је историја примања страних писаца одувек и историја културне и друштвене свести. Она је више од тезе славног Пола ван Тигема по којој се та историја ограничава на „проучавање међувеза двеју књижевности" - од тезе којом се она заправо претвара у споредну дисциплину „испитивања података о страним изворима и угледу на страни”.

Отуда је феномен књижевног превода вероватно најближи Ековом концепту отвореног дела. Opera operta је у том смислу творевина која у себи претпоставља отвореност за разне облике рецепције, отвореност дијалошког принципа и трајну недовршеност. Она провоцира различите перцепције и тражи увек ново разумевање, које се мења с изменом лингвистичке, историјске и цивилизацијске ситуације. Али у феноменологију књижевног уметничког дела, за коју је са више разлога нераскидиво везан и проблем превођења, спада и супротна теза: да мора постојати нека априорна и објективна, непроменљива вредност уметничког дела затвореног и довршеног у себи. Другим речима, врхунска дела поседују 
оно што је Теодор Адорно назвао „ванвременским језгром истине”. Поседују га чак и у време кад је дело било оспоравано или кад - неким случајем - још није било ни пронађено. Ту више није далеко ни Моргенштернова апстрактна теза да истинским оригиналима не могу да науде ни рђаве репродукције.

Но, без обзира на то да ли је превод резултат пуког случаја или свесног ситуирања у оквире друштвених, генетско-структуралних или индивидуално-психолошких паралелизама, он се, као специфичан облик књижевног деловања, понекад потпуно укључује у генетски развој и у друштвено-типолошку ситуацију нове средине. У свом пасивном и активном виду, који се креће од реминисценције и подударности до подстицаја и подражавања, овакав превод се најлакше уочава у разноврсним облицима тзв. филијације или надовезивања. Етничке и уједно црквене везе одређују, на пример, однос старе српске књижевности према ћирило-методијском наслеђу, као и фазу рускословенске и славеносербске епохе, па и даље.

Могући су, међутим, и супротни примери код којих се филијација, такорећи, вештачки одржава. Аутори Фландрије, који се нису служили француским језиком, били су упућени на немачке преводе, некадашњи „словенски есперанто”, да би уопште били читани у источноевропским земљама. И опет се тзв. хоризонт очекивања показује као пресудан приликом избора. Превођени су, наиме, углавном они аутори који су одговарали познатој, и са светском славом фламанског сликарства повезаној представи о Фландрији као земљи чији је народ прожет „мистицизмом” и „сензуализмом” (Н. Dizerink). Нема, зацело, неког другог стереотипа који се толико употребљавао као овештала фраза о неизменљивим националним особинама. Ау- 
тори националних програма, књижевни дилетанти и професионални преводиоци, антрополози и политичари, самоуверено су понављали, и још увек понављају у неподношљивом критичком вишегласју, овештале представе о наводно трајним својствима која непосредно одређује уметничку праксу и њену вредност.

Нема, такође, никакве сумње да релевантност превода са становишта историје књижевности намеће и специфичне задатке у реконструкцији вредносне хијерархије у књижевности одређене епохе. Но кад год се истражује судбина или теорија превода, неопходно је поново открити функционалност којом су били прожети не само преводи истакнутих дела која су писци сачували у сећању, већ и она маса остварења, безначајна данас, која их је подупирала, а ваља такође поново осветлити оно мнење које их је окруживало, као и социјалне тенденције подстакнуте ставом сличним оном око ових дела, која су данас мање или више веродостојни културни споменици.

Ренесанса и хуманизам покренули су талас превођења с превода, превода из друге руке - са латинског језика. У првом реду радило се о изворно грчким, арапским или хебрејским списима. Француска књижевност 16. века обухватала је, на пример, доста широк спектар од Раблеових гротески до класицистичког подражавања антике. Седморица аутора Pléiade захтевали су програмски преображај народног у књижевни језик, уз непрестано угледање на лексику и структуру античких дела: „amplifier la langue francoyse par l'immitation des anciens auteurs grecz et romains" (J. du Belley, La Défense et illustration de la langue française, 1548). И док су једни то подражавање дезавуисали као афектирану стилску вежбу, други су, живећи и преводећи у „варварском” и „вулгарном” времену, видели у томе повратак изворима и драгоцено богаћење сопственог језика. 
Превод је био ипак најизразитији мотор, покретач књижевне рецепције све док је латински играо посредничку улогу, а то значи, пре него што ће француски језик постати „домовина индиректних превода” текстова из шпанске и енглеске књижевности. У 17. и 18. столећу преводило се, наиме, претежно са француског као језика-посредника који је нудио шпанске и енглеске, повремено и италијанске текстове. Није необично што ни Лесинг није преводио Сервантеса на немачки са шпанског оригинала него са француског превода, истина „веома рђавог и неверног”.

Синдром „критике мадам Готшед”, супруге знаменитог професора и поетолога, учене даме која је - згранута обимом француских одступања - сама превела бурлеску Rape of the Lock Александра Поупа, дуго је био познатији од самог феномена „индиректног превода”. Цитира се и данас, иако то свакако није био једини разлог због којег је улога француског језика као посредника дуго времена била потцењивана. Трансформације до којих је долазило у овим преводима, биле су веће него код латинског посредовања: са преводом је, наиме, преузимано и мишљење преводиоца, па и укус оног дела публике коме је тек био намењен. Једно од првих сведочанстава представљају француски преводи италијанских новела (Бандело) које су, у веома измењеној верзији, реципирали Шекспир и Калдерон.

Данас, међутим, ови индиректни преводи буде све веће интересовање, не само из угла естетике рецепције, која у њима види пристајање на текући укус читалачке публике. Они су и по много чему другом имали важну функцију, иако је романтичарска идолатрија оригиналности за дуги период дискредитовала преводе из друге руке, снажно потискујући значај, занимање и свест о свим њиховим занимљивим метаморфозама. Бескрај- 
на скала тих одступања која сежу од незнања и несвесних грешака до свесне пародије или сатире, естетски је, захваљујући суштини својих настојања, укључена у космос евокација за које је литература способна. У коментарима Чосерових Кентерберијских прича помиње се да је прича о стрпљивој Гризелди, лику европског фолклора, заправо само превод Петрарке, а сам lauriat poetae, Франческо Петрарка, није крио да је „дирљиву” причу о Гризелди преузео од Бокача, па чак ни у потпуности од тог славом овенчаног „првака књижевне фирентинске Комуне”, него од свог доброг пријатеља.

У књижевности барока, опет, границе између превођења и подражавања често сасвим нестају. Популарност појединих жанрова (пикарски роман) иницира читаву поплаву превода, прерада и обрада, при чему није прављена принципијелна разлика између превода и властитог песништва. Радња Сервантесових Узорних новела преноси се на познатије и присније тло, у „светски чувен град Праг”.

Парадоксалност односа између превода и оригинала, са данашње тачке гледишта посматрано, била је потпуна. Тако у Немачкој, у седамнаестом веку, када су француски и латински словили као језици књижевности, није постојала права потреба за превођењем. Њима су мање-више владали сви писмени људи. Преводило се, међутим, веома много. При томе су дела, којима бисмо ми данас - због снажног изобличења изворника којем захваљују за повод свога настанка - пре доделили предикат оригиналности, изричито означавана као преводи.

Тако је Ђовани Батиста Лали (Lalli) своју Eneide travestita (1633), превођену и цитирану још у 19. веку, оценио у предговору као - превод. Учени Лали, преточио је своје ниподаштавање Вергилија у тзв. „макаронске”, духовито искривљене, шаљиве стихове, помешане 
с француским речима. Бројне мистификације су карактеристичне и за наредне епохе. Али, чак и оно што је верно превођено, што се нипошто није могло подвести под тај макаронски стил као специфични културни феномен - а то важи за барокни период од Јустуса Георга Шотела до немачких ,језичких друштава” - уследило је више из намере да се реторички увежбавају и усавршавају изражајне могућности матерњег језика у класичним облицима и родовима.

Опсег преведене књижевности непрекидно расте; њена функција се, наравно, мења. Као део литерарног корпуса, преведена књижевност, међутим, великим делом и даље остаје део националне књижевности - баш као што ће Бранислав Нушић, не само због свог псеудонима Бен Акиба, бити прихваћен у Египту као домаћи писац! Тако ће Јунгманов чешки превод Шатобријана, који према анализама Водичке знатно одудара од оригинала, деловао еволутивно-стваралачки, новаторски на плану синтаксе и стила. Карактер словенских књижевности је још на почетку XIX века био такве природе да је превод имао функцију оригинала. То уједно значи да нам је превод, у свом одступању од оригинала, јасније откривао домаћу ситуацију него што је то случај данас.

Али у осталој књижевној продукцији играју и други аспекти важну улогу. Све нам то, разуме се, у синоптичком прегледу различитих европских теорија превођења, намеће следећи закључак: сем остварења дела која се афирмативно надовезују на текстове претходних раздобља, манифестујући тиме континуитет, односно конформност развитка, могућ је и контроверзни облик деловања превода, који ствара дисконтинуитет у литерарном надовезивању. То се, пре свега, односи на разноврсне опозиционе облике рецепције.

„Продуктивна противречност”, коју је Андре Жид назвао influence par réaction, и која је у историји романа 
деловала као еволутивна покретачка сила, може имати за последицу различите облике рецепције: одговор на постојећа дела у смислу коректуре, својеврсне реплике, намере да се ствара „сасвим другачије”. Анти-јунаци, разни анти-Хамлети, анти-Вертери и жовијални ликови Фауста (Жари, Валери), налазе своје књижевне пандане у контрастним ликовима разних Ричардсонових Памела што листом отеловљују супротност прогоњеној невиности без заштите. Да појам „репликативне рецепције” не представља контрадикцију, потврђују, уосталом, већ и преводи 17. и 18. века који тендирају ка пародирању (J. V. Stakelberg).

То се у великој мери односи и на књижевне суплементе који у овом периоду више не представљају учене реконструкције класичних дела, него мање амбициозне допуне новијих дела која су, као што је то био случај са романима у писмима, остала фрагментарна, или су тако изгледала - кроз укључивање нових кореспондената. Међутим, код ових апокрифних наставака, које је било тешко разликовати од оригинала, реч је уједно о репликама које се у почетку ослањају на своје изворе, али које, временом, прилагођавајући се одређеним очекивањима публике, постају супротност онога чему су у почетку тежиле. То је скривена судбина „дописиваног оригинала", то је његова невидљива позадина - тајна историја судара две литерарне идеологије и две супротстављене естетике - нормативне преводилачке догме и слободне имагинације.

„Преводилачка маска” је опробана конвенција којом се романописци служе представљаући се као преводиоци (Монтескје), приређивачи (Лакло), издавачи (Русо) или редактори (Балзак) наводно аутентичних докумената. Она се не односи само на опрему и структуру текста, као у случају италијанско-фран- 
цуског издања Турских писама будванског пустолова, конте Зановића, објављених у Дрездену 1776, већ и на њену често агресивну естетику дигресије и неочекивано преплитање наративних нити. Као део расправе о иновативности, повезаној са методама и последицама превођења, теорија има обавезу да укаже и на наличје ових поступака. Занимљиви су овде чувени суплементи романа шпанског „златног века”, који започињу афирмацијом а завршавају негацијом. Они тендирају да оно што је у оригиналу првобитно било против норме и конвенције, претворе у конвенцију, да га срозају и обезвреде, при чему се негда еманципаторско уметничко дело претвара у „потрошачку књижевност”. Тако се Португалска и Перуанска писма у суплементима редукују на познату схему хеленистичког љубавног романа и тиме лишавају оне слободе коју је чинила њихова литерарна и морална изазовност.

Међутим, диференцирана историјска свест у XIX веку доводи, с друге стране, и до потпуног расцепа престабилизоване хармоније преводиоца и читалачке публике. Као што тзв. „трансгресивни аутори” у овом столећу, на пример Флобер, стварају дела која су у извесном смислу уперена против („емпиријске”) публике, тако се у исто време неки преводиоци усуђују да драстично мењају очекивања публике. Оба момента: изоштрена историјска свест и еманципација писца од очекивања публике, утичу на настанак екстремно „потуђених" превода, пре свега Хомера (Leconte de Lisle) и радикално историзованог Дантеа (Émile Littre).

Погрешно је, међутим, сматрати превод за књижевноисторијски фактотум. Тој мистификацији, којој нагињу неке савремене теорије рецепције, ваља се одупрети из неколико разлога.

1) Утицај античке књижевности у новом веку огледа се на северу Европе у примању и повременом опо- 
нашању оригиналних дела, при чему преводи играју често секундарну, то јест, временски постериорну улогу. Стваралачка рецепција Шекспира почела је на европском континенту знатно пре појаве најзначајнијих превода. Довољно је поменути утицај Шекспира и путујућих глумачких дружина које су гостовале широм континента на енглеском језику. Управо је жестока борба за превласт разних путујућих позоришта у средњоевропском културном кругу, борба између модела елизабетанског театра, италијанске комедије дел арте и упорних позива на реформу позоришта по узору на франиуску класику, довела до стварања самосвојних облика.

За имена Поупа или Јанга - зачетника сантиментализма, чије дело Night-thoughts је у Немачкој играло значајнију улогу него у Енглеској - показују каталози књига да су - сем превода на француски (Le Tourneur), италијански и немачки - у више наврата били штампани у Немачкој на енлеском језику, па отуда њихов утицај није зависио само од превода.

Аутори такозваних малих књижевности су у принципу реципирали оригинална дела страних писаца; та пракса се одржала све до 20. века. Па и данас тешко разумљиви утицај Данца Холберга (Holberg) на комедију просветитељства и романтизма не почива на преводима. Ови су уследили - око 1815. године - када је Холберг постао једна не само етаблирана, него и опсолетна, превазиђена књижевна инстанца. Што се њега лично тиче, ствар је још необичнија. Писац драма и радо читаних Моралних мисли (Moralske Tanker) постао је 1717. године редовни професор универзитета у Копенхагену, те се више није сматрало прикладним да мислилац и научник таквог реномеа губи време на сасвим фриволне ствари као што је театар. 
У вези, пак, са чувеним случајем Гетеовог Вертера може се навести као куриозум да је превод био забрањен у Данској, иако то није имало никакве практичне последице. Сви образовани Данци су - уосталом као и данас - без тешкоћа читали оригинал. Финије језичке конотације се, додуше, у таквим случајевима губе, али оне се губе и приликом превођења. Lost in translation.

2) Посебан облик изневеравања представља, међутим, појава, када се приликом превођења има у виду само одређени слој публике, чему онда „секундира” одговарајући слој језика на који се преводи. Преводи Андерсенових бајки на енглески и немачки лишени су иронизма у језику и распореду грађе, али су зато испуњени архаизмима у смислу Грима и других. Осећамо - барем данас - како су вршена и одређена прилагођаваға духу народног човека код Доситеја. Прошавши кроз духовни утицај грчких црквених реформатора, немачког протестантизма и француског и енглеског рационализма, овај српски Сократ је издавао збирке савета учених људи „с језика разних преведених”. Прилагођавања су вршена у смислу тзв. редакције, али и често насилне редукције европских мудрих, поучителних мисли.

Та врста прилагодљивости била је нарочито интензивна у доба просветитељства, када су вредно реципирани антички, персијски, арапски, познолатински, провансалски, енглески, италијански и шпански модели књижевнојезичких форми, да би се уз њихову помоћ нашао домаћи облик за душевне или политичке импулсе и феномене - често у нескладу с мисаоним садржајем. Овде треба застати. Било би, наиме, бесмислено поистоветити значај преводилаштва са формом - како то, понегде, чине деконструктивисти - али у томе ипак треба видети симптом: обликовање је увек условљено потребом да се прилагоди разумевању. 
Песничке слике, чија би безначајност пала у очи када би биле исказане у прози, оснажене су помоћу ритма и риме, дотеране помоћу строфе. Змајеве позајмице и бројни препеви с немачког („по Милеру”), заправо су нови оригинали. Много се лакше читају него данас већ заборављени изворни текстови. Као да су превод и оригинал заменили улоге. Па ипак, стихови често делују непоправљиво идилично, интимистички, а понекад и наивно до анегдотичности која тражи уточиште у спокојству чиста срца. Змај је брзо, често без предаха, задихано стварао за потребе тренутка. Успешно је „посрбљавао и поправљао” епиграме, у којима је сачувана само мисао оригинала.

3) Најтежи облик манипулације представља, међутим, цензурисање, мање или више дискретно изостављање, дотеривање или улепшавање текста из којег се уклањају опасно алузивна или вишезначна места ad usum Delphini. На њих се највише односи чувена изрека да књиге имају своју судбину. Habent sua fata libeli. При том се не мисли на мишеве и крадљивце књига, него на институцију цензуре. Али кад пређу границе држава или језика, књиге доживе још неизвеснију судбину - судбину превода. Ту показују своје друго лице, наизглед скривено иза актуелног ентузијазма партиципације у стварању новог, свеевропског и политичког простора. То је лице које може бити нагло затамњено или измењено, као у закривљеном огледалу. Само је тако уопште могуће да се један прогресиван писац, какав је несумњиво био норвешки писац Бјернсон, мимо његовог знања пренесе у регресивне (немачке) текстове.

Супротној судбини надао се Хорхе Луис Борхес. Тежња да буде схваћен „у готово сваком смислу осим у приземном", и притом остане оригиналан и свој по сваку цену, нагнала га је на стару досетку: да се његов текст 
схвати као наводни превод приче написане на другом језику, у некој другој земљи и другој култури - приче коју ће онда описати, приказати, рецензирати као дело непознатог аутора. Треба ли рећи да је тиме призвана у сећање обимна митологија огледања текста у тексту, одражавања у огледалу, преводиоца као ауторовог двојника који онеобичава његов лик, а ипак дозвољава да се у тим цртама назре њихова инваријантна основа? Објашњавајући, међутим, Борхеса искључиво у његовим омиљеним терминима огледала и лавиринта, као да прихватамо слику коју он прави о себи као следбенику романтичарских досетки деветнаестог века. Утицај и бескрајно ширење превода кроз простор имагинарне библиотеке светске књижевности која отвара огромне могућности „потенцијалне књижевности”, свакако га чини настављачем идеје о тзв. „прогресивној универзалној поезији” - о његовом величанству Преводу као идеалистички замишљеном, али често на разне начине осујећиваном покушају, отежаном критичким дигресијама о покусном феномену сливања и примене различитих дискурса и стилова изражавања. А уједно о производу с ограниченим јемством.

Видели смо да је тешко повући оштру црту између повести и културно-историјског значења превода, с једне, и историјата деловања, односно утицаја појединих превода кроз столећа у различитим језичким и културним просторима, с друге стране. Превођење несумњиво представља средство језичке комуникације, али оно уједно представља и посредовање литерарних, научних, културних, политичких и социјалних сазнања и искустава која су одувек отварала видике историјског развоја људске цивилизације уопште. Данас оно практично иде, уопштено говорећи, у ред оних нехијерархијских, мобилних структура, сачињених 
од променљивих величина чије се међусобно супротстављене перспективе могу помирити у далекосежну визију човекових тежњи. Ту је, додуше, крајње амбивалентна позиција поезије, тачније: утицај појединачних песама које, свака на свој начин, будући иконичке творевине, на свом мајушном простору ужижују неко огромно поље искуства.

Међутим, данашњи универзализам културе се ипак битно разликује од - на пример - средњовековног универзализма, у чијем средишту је као посредник стајао латински или неки други опште признати културни језик, преко којег су у већини дела националних књижевности вариране традиране теме, изведене из библијских, античких, оријенталних или витешких мотива. Све те теме су, осим тога, почивале на чврсто кодифицираном аксиолошком и идеолошком органону хришћанства.

У последњих две стотине година, превод, насупрот томе, постаје средство масовне комуникације, нека врста реакције на вавилонску замршеност језика, која наизглед потврђује познати афоризам Октавија Паза: да је култура, особито данас, у основи превод низа превода. Мишљење, међутим, да филолошко превођење, као својеврсни кохезиони елемент културе, доводи до одређене униформности светске књижевности, не води рачуна о комплексности феномена којем се може приписати управо супротан ефекат. Стилови, поетике, типови књижевности који су у двадесетом веку надирали у таласима (Хемингвеј, Кафка, Борхес, магични реализам), представљају заправо неку врсту катализатора у стварању индивидуалне поетике и стила које, уколико није епигонално, резултира разноврсношћу облика уметничког казивања. Ваљало би стога оснажити претпоставку по којој би једна обновљена универзална res 
publica literaria, која је, некада, представљала владајући модел, могла да се потврди и у данашњој глобалној индустрији културе.

8.

Критика чистог превода. - Као што ни Кантова критика чистог ума не одбацује природни задатак ума, већ га, напротив, изводи на чистину, тако и критика чистог превода има позитивне последице приликом испитивања задатка који превод задаје књижевној историји. Ако су старе мудрости исмејане, то и даље не значи да су мање истините. Преводиоцу најбоље пристаје улога историјског посредника. Он чита, мисли и осећа заједно с аутором књижевног текста. Зато га скоро увек прожимају противречна осећања: истовремена осећања надмоћи и подређености у односу на аутора. Јер он се у исти мах креће изнад и испод површине његовог текста. На тренутке помишља да је мање вредан у односу на оно што преводи, али верује да је надмоћан већ и због тога што је у стању да то преведе.

Као да у дубини колективне свести изнова просијава онај пресудни тренутак преласка са заједничког, гласног читања, на самотно, нечујно читање у себи. Пратиле су га, знамо, далекосежне последице. Слова су изгубила своју моћ над телом. Природни закон је сменила норма. Мит јунака замењен је митом онога који је дотле, безимен, певао о јунаку. Замењен је, дакле, аутором. Појава преводиоца учинила је феномене замршенијим. Утицај језика једног бића на друга бића само је унутарњи спиритуални динамизам ако се, идеалистички, посматра споља. Тиме се решава и Кантов проблем: како се слобода може помирити с ауторитетом. Ауторов ауторитет постаје преводиочева слобода. 
Ако идеја ове слободе има предисторију, има и епилог. Пре него што се баци у белину листа папира, преводилац се спрема за скок. За превођење као скок. Он мора да савлада увек исту препреку: да прескочи јаз између култура, да осети други сензибилитет и ментални склоп, да га пренесе у нови код, у други „фонт”. У слова уноси сву енергију словослагача, енергију крститеља што изнова именује - остајући притом невидљив, зачаран у тексту, у неку руку бестелесан, без сенке. Међу стално променљиве кулисе ставља бесконачно огледало, да би га на тренутке напустио и вратио му се да га потчини, али са таквом снагом, да оно, као под дејством резонанце која распрскава стакло, наједном није ништа друго до скуп светлуцавих делића новог калеидоскопа. Баш зато ће, већ у основи, пре него што се уопште постави, проблем лажне идентификације с текстом решен реалношћу препознавања.

Преводилац свакако може имати различите мотиве и циљеве због којих смисао текста раскрива, али и скрива. Због којих, уједно, у својој репродуктивној интерпретацији, одлучује о вредности и смислу оригинала. И због којих је, у крајњој линији, његова етика на највећој проби. Ни у једној другој традицији језиком обузетих теорија не може се, наиме, наћи таква маса нормативног морала. Етика превођења обично почиње са заклетвом на верност, али и на слободу, ону песничку, златну, да би потом транспоновала верност у „напетост односа" који владају између језика.

Враћајући се у њене теоријске оквире, постаје јасно да се и преведеној структури мора вратити историјска садржина, дакле она упоришта у стварности каква је оригинал имао, а језичка љуштура, какву преносимо из оригинала, мора примити у себе смисао, не нов и свакако не ванвременски, чак већ и проблемски патини- 
ран, али изворно његов и без сумње више по његовој мери од сваког другог каквог бисмо му сами могли домислити или подметнути.

О томе, уосталом, сведочи напор нових критички надахнутих нараштаја, који отвара и нове сазнајне могућности. Често сумњичен и оспораван, значај Деридиног бављења преводом лежи у провокацији. Доводећи у питање затечене ставове и преводилачке методе, он позива на ново промишљање и разумевање језика у његовој историјско-културолошкој димензији. Било је довољно да се уђе у Деридину библиотеку и да он, седећи, монотоно изговара маратонске монологе о превођењу, о „разликама”, о „напрслинама” и деконструкцијама, па да и највећи противник изађе претворен у постмодернисту, кога су заборав бића, нестабилност и апорије у традицији западне филозофске мисли - сви ти усуди метафизике - натерали да се окрене онто-теологији, појму који је његов омиљени мислилац Хајдегер дао једној форми мисли о „оном истинском”. Дерида је био много више од преводиоца. Поставши кошмар традиционалних књижевних тумачења, осудио је једнозначности као једну од наслеђених мантри, као генетску грешку свих идеала и метода тумачења.

Цела постмодерна, међутим, заједно с њим, извлачи својеврсну „кројачку” метафорику набора, фалти, шавова, ткања и текстуре из Бењаминове филозофије превода. Јер, његова се тајна, његово умеће, по њему, управо и крије у „наборима текста као ткања”. У предговору Tableaux parisiens (1923), Бењамин дословно каже да је преводилац заправо кројач који се разуме у ткање, у текстуру: „Језик превода обавија његов садржај попут краљевског плашта у широким наборима”. А тај садржај преводиочевог језика је заправо језик оригинала. Испод краљевског плашта се у виду садржаја 
не крије ништа друго до раскошно ткање, идентично с оригиналом.

Вавилонске куле (1991), тај Деридин коментар чувеног Бењаминовог коментара Задатак преводиоца, завршава се цитатом његовог ментора, угледног филозофа Мориса Гандијака (Gandillac), иначе доста непоузданог преводиоца са немачког: „До извесног степена сви велики списи, у највећој мери они свети, садрже између редова свој виртуелни превод. Интерлинеарна верзија Светог писма је узор или идеал сваког превода". Тиме се не мисли на смисао и дословност његовог превода, већ на оно што се догађа у тексту, на оно што je - непреводиво. Алудира се, по свему судећи, на једну необичну Бењаминову тезу из поменутог Задатка преводиоиа: „Преводилац има задатак да у језику на који преводи пронађе ону интенцију на основу које у том језику може да се пробуди ехо оригинала". Ту онда више и није реч о реституцији смисла, него о самом односу према језику као таквом, о његовом живом бићу, о бивствовану у језику.

„Превод је мртав! Живео превод!” узвикнуо је већ Ортега и Гасет у већ поменутом есеју Сјај и беда превођења (1937). Управо је та оптимистичка противречност постала омиљени парадокс деконструктивиста, које је привукла проблематика превођења. Следбеници Деридине Теологије превода брзо су уочили фрапантну сличност с деконструкцијом. Она стоји и на почетку свих даљих разматрања која доказују због чега се на томе мора истрајати, тачније: због чега је немогућ превод - могућ. Стога и не чуди проширење самог појма превода управо код Пол де Мана, који га поводом Бењаминовог Задатка преводиоца буквално поистовећује са деконструкцијом: „Оригинал се у процесу превођења деканонизира, он се редукује у свом стату- 
су, будући да немогућност превода почива на ломовима који постоје у оригиналу, али је њему, преводу, пошло за руком да их прикрије”.

Ова филозофија превода има свој скривени извор. Нећемо погрешити ако с пуним уверењем укажемо на појам псеудоморфозе Освалда Шпенглера, појам који је визионар „светских циклуса” позајмио из геологије и минералогије. Пренет на морфолошку перспективу превођења, он је остао непримећен. У стену су, каже аутор Пропасти Запада, затворени кристали минерала. Настају пукотине и расцепи. Вода постепено испира кристале, тако да преостаје само њихов шупљи облик. Долази до чудног укрштања. Испуњавајући празне облике који већ постоје, пунећи празне калупе за речи, све прозирније, и све мање чудно, преводна маса се и сама кристализује; аналогна душевност се излива у постојеће калупе и облике туђег живота - то је врста која се појављује на начин друге врсте. Из тог тако укрштеног ткива рађа се једна интегрална визија превода, за коју не бисмо знали рећи да ли је мање логички-егзактна или је више поетско-визионарска, зато што обједињује обоје. И као што се псеудоморфоза састојала у томе да се источне цркве преведу у западне култове, тако се и превод ослобађа од везаности за оригинал. Он је свест која га савлађује, господари њиме, одриче га, па чак и уништава.

Тиме се враћамо на почетне тезе овог рада. Ако је оправдано питање у којој се мери продуктивним или непродуктивним може сматрати насилна актуелизација Хајдегера према интелектуалном профилу нових француских филозофа; ако, с друге стране, сам Хајдегер својим преводима, својим етимолошким анализама и својим „повратком” предсократовцима тражи нову дистанцу према старој традицији заговарајући пуну 
деструкцију западне метафизике - онда то свакако има и одговарајуће последице за теорију превођења.

Приближавајући се овим питањима споља, као конгломерату проблема који се намећу науци о превођењу данас, и скидајући слој по слој оних наслага које су у међувремену затрпале и удаљиле суштину проблема, сама питања се могу учинити методолошки преурањена, али њихово је место овде, као и одговору, јер управо одавде, из спољне перспективе гледања на превод, добијају и питање и одговор сву оштрину и значај који им иначе припада.

Превођење нам се доиста указује као део програма једне „инсценације страног”, утемељеног у сопственој култури. Јер, да је оно део литерарне имагологије и културне иконологије која барата сталном залихом слика и представа што говоре више о свом него о страном - у то нема никакве сумње. Штавише, оно повремено прети да постане нарцистичка пројекција сопствених жеља, не само на теоријском плану. С правом се подсећа на околност да је сва теорија и пракса европске авангарде, од футуризма и дадаизма преко надреализма и Баухауса до теоретичара Лингера и Бењамина, у знаку поетике деконструкције, која на више начина упућује на феноменологију превођења.

Тај први модел превода се уистину може сматрати пројекцијом властите стварности. То је позната страност. Насупрот томе, Ролан Барт у свом разглашеном тексту L' empire des signes (1970) сања о једном затвореном свету о чије зидине се разбија у парампарчад сва наша присност, све наше познавање ствари. Он сања о једном непреводивом језику, о царству знакова које чини могућим само једно: descendre dans l'intraduisible. Тај други модел ствара недоумицу: није ли преводилачка доктрина ипак непрозирна, није ли то ковчежић у 
коме се чува света тајна. Јер, ако се и у теорији види само супротни модел рационалности, само „ледена пустиња апстракције” (Бењамин) - то не значи да нам се, заузврат, нуде тезе које су мање апстрактне. Или мање тајновите.

Дистанцирање од властите културе јесте сан о сасвим друкчијој култури. Као сан у сну, али сан свестан свог снивања о некој другој историји, другом језику, другој сликовности и другом начину мишљења. Овај други модел све више еманира из духа времена. Он радикализује искуство страности и ствара од њега алтернативу властитој историјски и културно кодираној традицији коју сматра угроженом. Он је против-модел у односу на властиту културу као такву. Следствено томе, ту више није реч о неком сопственом одразу у огледалу страног, већ о контрастној слици, о контрафактури властите културе - са свим потешкоћама које са собом носи.

А оне се некад привидно разрешавају једноставном жељом да се буде „бољи од оригинала” (Л. Костић, С. Винавер). Нема, уосталом, земље у чијој се преводилачкој култури нису одржавала такмичења у новим препевима ремек-дела, у немогућим подухватима оптимирања квалитета. Ти духовни турнири трају из генерације у генерацију, не само зато што нови преводи представљају пробни камен и вечити изазов, него и зато што Шекспир и Бодлер представљују различите „системе могућих доживљаја”. Свака епоха има свог Фауста или свог Уликса. Текстови имају сопствену интелектуалну историју, али свака епоха види у истим делима другачији смисао. Потребу за новим преводима подстиче екстракт нових етичких идеала и естетских појмова, а њихов појавни облик можемо, у духу природних наука, назвати особеним језичким хабитусом. 


\section{Извори и литература}

Benjamin, Walter. Die Aufgabe des Übersetzers, in: Gesammelte Schriften, hrsg. v. Tillman Rexroth, Suhrkamp Verlag. Frankfurt a. Main, 1980.

Venutti, Lawrence. The Translators Invisibility. A History of Translation. New York, 2008.

Goethe, Johann W. V. Sämtliche Werke. Briefe, Tagebücher und Gespräche ['Frankfurter Ausgabe'], 40 Bde., ed. Friedmar Apel, Hendrik Birus [et. al.], Frankfurt/Main 1986-1999.

Mounin, Georges. Problèmes théoriques de la traduction. Paris 1963.

Nida, Eugene. Toward a science of translating. Brill 1969.

Spingarn, Joel Elias. A history of Literary Criticism in the Reaissance. New York, 1899.

Slobodan Grubačić

\section{A CONTRIBUTION TO THE CRITIQUE OF PURE TRANSLATION}

We have long been uncertain, ascending through the lines of originals and translations, and we are again at the top of a hill beneath which a mass of theoretical ice undreamed-of lies hidden. This invisible world has not yet emerged, despite the belief that there are no secrets any more, that she has been awakened, she who sleeps a glass casket - the goddess of translation, breathing another life into the literary work. However, even the one who does not know that translation is one of the most mysterious adventures knows that the connection between the original and the translation is long and deep. Whilst establishing this connection, through time, space and languages, the privileged place is retained by the mediator, the translator. Although the translator resides in the shadow of the text, in his subsequent imaginative enthusiasm he walks the same paths of creative imagination that the writer has gone through. 